\title{
OSMANLILARDA OTOPSI
}

\author{
AHMET YÜKSEL*
}

\section{Giriş: Otopsi Kavramı}

Otopsi kelimesi "auto" ve "opsis" kelimelerinden oluşan bir bileşimdir ve "kendini (içini) görme" anlamına gelmektedir. Otopsi; ölüm olgularında, ölüm sebebi, ölüm zamanı, ölenin kimlik tespiti, ölümün; kaza ml, cinayet mi, intihar mı, yoksa doğal ölüm mü olduğu hususlannda aydınlatıcı bilgiler elde edilmesine yardım eden, adlî veya tubbî gerekçelerle uygulanan çok önemli bir inceleme yöntemidir. $^{1}$

Otopsi ameliyatları hususî ve adlî olmak üzere iki kısma ayrilır. Hususî otopsiler ya şahsın hayatta iken hazırladığı/hazırlattı̆ı vasiyeti üzerine yapılır ya da ilmî maksatla ailenin izni alınarak yapılır. Ayrıca hususî otopsiler bulaşıcı hastalık şüphesi varsa hekimin isteği üzerine de yapllı. Adlî otopsiler ise adliyeyi ilgilendiren konularda hekimin teklifi, hâkim ve savcının kararı ile yapulır. Adlî otopsi birisi adlî tabip olmak kaydıyla iki hekim tarafindan yapılır. Mecbur kalındığı takdirde tek hekimle de yapilabilir. ${ }^{2}$

Bu çalı̧mayı daha çok ilgilendiren adlî otopsi sayesinde ölüm nedenine ait kuşkular ile olgu hakkındaki gereksiz tahminler de ortadan kalkar. Otopsi ile gerçek ölüm nedeni ve şeklinin belirlenmesi, ileride ortaya çıkabilecek sorunların cevaplandırılmasına olanak sağlar. Otopsi, ölüm nedeni veya şekli ile doğrudan ilgili olmayan ancak bazı yönlerden önem taşıyan pozitif veya negatif bulguların tespit edilmesinde de yardımcı olur. ${ }^{3}$ Ölü muayenesi ve adlî otopside amaç; t tbbî otopside olduğu gibi ölüm nedenini, ölüm şeklini ve orijinini, özellikle faili bilinmeyen cinayetlerde faile ait bulgu ve kalıntıları, ölüme yol açan alet türünü, birden fazla kişinin olaya

•Yrd. Doç. Dr., Cumhuriyet Universitesi, Edebiyat Fakültesi, Tarih Bölümü, Sivas/TÚRKIYE. ahmetarih@hotmail.com

' Şemsi Gök, Adli Tipp, İstanbul 1991, s. 36

${ }^{2}$ Salih Yaşar Ozden, Adli Tip El Kitabı, Istanbul 1993, s. 65.

${ }^{3}$ Adli Otopsinin önemi hakkında daha fazla bilgi için bkz. Zeki Soysal-S.Murat Eke-A.Sadi Çağder, Adli Otopsi, I, Istanbul 1999, s. 7-14. 
katılıp katılmadığını, birden fazla alet kullanılıp kullanılmadığını, zehirlenme olgularında toksik maddeye ait kalıntılan ve diğer kanıtlanı ortaya koymaktır. ${ }^{4}$

\section{A-Adli Tıp ve Otopsinin Tarihsel Gelişimi}

Adlî tup; suçlunun toplum düzenine uymayan eylemlerini ve bu eylemler neticesinde ortaya çıkan hadiseleri (yaralama, ölüm, zehirleme vs.) suçlunun hüviyetinin saptanması ve cezaî sorumluluk açısından inceleyen bir bilimdir. ${ }^{5}$ Ayrıca " $t b b \hat{\imath}$ bilgilerin, bu bilgilerle aydınlanması kabil durumlarda hukukî ve cinâ hadiselere uygulanması isi" de adlî tıbbın en genel tanımı olarak değerlendirilebilir. Daha Eski Mısır, Yunan ve Roma medeniyetlerinde hukuk ve tup ilişkisini gösteren işaretler varsa da, 16. yüzyıla kadar adlî tıbba ilişkin önemli bir uygulamaya rastlanılmamıştır. Ancak o yüzyılda, 1566'da Ambrois Pare Paris'te ilk otopsiyi yaparak ${ }^{6}$ adlî tıbbın babası unvanını almıştır. Ardından 1602'de İtalyan Fortuna Fidelli bu konudaki ilk büyük eseri kaleme alacaktır. 17.yüzyıla gelindiğinde ise gerek Fransa'da gerekse Fransa dışında konuya dair pek çok eser neşredilecektir. Nihayet adlî tup dersleri ilk defa 1650 yılında Almanya'da Leipzig Úniversitesi Tıp Fakültesi ders programına girmek suretiyle okutulmaya başlanacaktır. Sistematik ve bilimsel anlamda adlî tup çalışmalan ise 19. yüzyılın ilk yıllarında başlayacak, ${ }^{7}$ bilim ve teknoloji alanındaki gelişmeler sayesinde de ayn bir bilim dah haline dönüşecektir.

\section{B- Osmanhlarda Adli Tip ve Otopsi}

\section{1) Kurumsal Gelişim}

Osmanlılarda adlî tubbın batıyla hemen aynı tarihlerde başladığı ve bu hususta oldukça büyük bir mesafenin kat edilmiş olduğu mesele üzerine mesailerinin uzun bir kısmını ayırmış olan çoğu araştırmacı tarafindan tarihî vesikalarla saptanmıştır. Adlî tıbbın özüne uygun olarak; kişilerin ölüm sebeplerinin anlaşılabilmesi ve suçluların saptanabilmesinden imparatorluk idaresi kendisini mesul tutmuştur. Bu anlayış doğrultusunda girişilen otopsi ameliyatlan merkezî idare tarafindan "her şeyden evvel asayiz̧in ve kamu hukukunun temin ve muhafazasında önemli bir nokta"s olarak tarif edilmiştir.

${ }^{4}$ Metin Orsal-Ufuk Katkıcı, Adli Rapor, Sivas 1991, s. 27-28.

Adnan Oztürel, Adli Tip, Ankara 1971, s. 1; Adlî tubbın tarifi, sahası, meslekî ve sosyal yönleriyle ilgili olarak bkz. H. Cahit Özen, Adli Tip Ders Kitabı, İstanbul 1980, s. 1-3.

${ }^{6}$ Bazı kaynaklarda ilk otopsinin yine Fransa'da, ancak 1374 senesinde yapıldığına dair bir bilgi bulunmaktadır. Bkz, Oztürel, a.g.e., s. 2.

${ }^{7}$ Dünyada ve Türkiye'de adlì tubbın aynntılı bir tarihçesi için bkz. Ozen, a.g.e., s. 1-9.

${ }^{8}$ BOA, DH.MKT, 569/37; 28 Cemaziyelevvel 1320/2 Eylül 1902. 
Osmanlı "Adli Tıp Teşkilatı"nın kuruluş ve gelişimine yönelik idarî ve sosyal düzenlemeler ise II.Mahmud (1808-1839) döneminin sonlarında başlamıştır. Özellikle 1827'de kurulan Tıbhâne-i Amire ile 1832'de kurulmuş olan Cerrâhhane-i Âmire'nin 1836 yılında "Mekteb-i Tıbbîye" adıyla birleştirilmeleri Osmanlı tup tarihine mükemmel bir ivme kazandırmıştur. 1839 senesinde Galatasaray'a nakledilen Tıbbiye Mektebi "Mekteb-i Tıbbiye-i Adlîye-i Şâhâne" adını almıştır. ${ }^{9}$ Bu okulda, Viyana'dan getirilen Dr. Charles Ambroise Bernard ${ }^{10}$ adlì tup derslerini ilk kez 1841 'de "Tibb-1 Kanunî" adı ile vermeye başlamıştır." Nihayet, Dr. Bernard'ın ısran üzerine Sultan Abdülmecid (1839-1861) 1841 yllında kadavra disseksiyonuna (teşrih/dissection: kesip ayırma/açımlama) ve Hıristiyan ölülerinin otopsisine izin veren bir ferman yayımlamış ve böylece ilk otopsi başına sırık düşerek ölen bir işçinin cesedine uygulanmıştır. O yıllarda dinî kaygı ve korkular nedeniyle Müslümanlara ait cesetler üzerinde otopsi ameliyatı icra olunamamıştır. ${ }^{12}$

1857 yılına gelindiğinde Sultan Abdülmecid'in fermanıla Meclis-i Umur-1 Tıbbiye'ye"13 bağlı "Tıbbî ve Adlî Komisyon"un kurulmasıyla Türkiye'de adlî tıp teşkilatının ilk adımı atılmıştır. Sultan Abdülaziz devrinde (1861-1876), 1867 senesinde ise ilk sivil tup mektebi olarak Mekteb-i Tıbbiye-i Mülkiye açılmıştır. ${ }^{14}$ Açılış gayesi "her şehir ve kasabada birer tabip bulundurarak halkan sihhatine hizmet etmektir. "15 Bundan iki yıl sonra neşredilecek olan İdâre-i Tıbbiye-i Mülkiye Nizâmnâmesi ile de ülkedeki genel sağlık işlerinde yeni bir düzenlemeye gidilmiştir. Buna göre sivil sağlık hizmetleri için Nezâret-i Tıbbiye-i Mülkiye adıyla bir idare kurulmuş, bu idare-

"E. Kadri Unat-Mustafa Samast, "Mekteb-i Tıbbiye-i Mülkiye", I. Türk Tip Tarihi Kongresi, Ankara 1992, s. 11 .

10 Dr. Bernard'ın Viyana'dan getirtilmesi Türk tubbını çağdaşlaştırma girişimleri bakımından önemli bir dönüm noktası olarak kabul edilmektedir. Bkz. Esin Kâhya, "Bizde Disseksiyon Ne zaman ve Nasıl Başladı", Belleten, C.XLIII, S.172, Ankara 1979, s. 746.

1 Bazı kaynaklarda ilk adli up dersinin yine bu okulda, ancak 1849 senesinde ve Dr. Serviçen Efendi tarafindan verilmiş olduğu kayıthdır. Bkz. Oztürel, a.g.e., s.4.

${ }^{12}$ Şemsi Gök-Cahit Özen, Adli Tibbun Tarihgesi ve Teşkilatlanması, Istanbul 1982, s.1; Soysal-EkeÇağdır, a.g.e., s. 5-6.

${ }^{13}$ Mekteb-i Tıbbiye Șâhâne'nin kuruluşundan sonra, 1840 Mayss ayı içerisinde Mekteb-i Fünûn-1 Tibbiye-i Şâhâne'de Meclis-i Umûr-1 Tibbiye-i Mülkiye namıla bir meclis kurulmuştur. Bu meclisin kuruluş amacı gerek İstanbul'da gerekse taşrada bulunan bütün sıhhî sanat erbabının (tabib, eczacı, ebe, hemşire vs) ellerinde diplomalan olup olmadiğım kontrol etmekti. Başlanģ̧̧aki salt amacı bu olan meclise, sonradan bütün ülke düzeyinde sağlık memurlannın atanması kontrolü vb. görevler verilmiştir. Bunların yanısıra önemli bir diğer görevi de "...Mahakim-i Adliveden gönderilen cerâim ve cinâyatın mesâil-i mühimme-i abbiyesini hâl ve tedkik eylemek ve mesmümen vefat edenlerin ahşâlanm teşrih ile semlerini taham eylemek ve... bu babda taşrada etıbba tarafindan verilen raporlan tedkik eylemekti." Bkz. Sedat Bingöl, "Tanzimat Ilkeleri Işı̆gnda Osmanlı'da Adli Tababete Dair Notlar", Tanh Araştırmalan Dergisi, C.XXVI, S.42, Ankara 2007, s. 39.

It Gök, a.g.e., s. 2.

${ }^{15}$ Feza Günergun-Nuran Yıldırım, "Cemiyet-i Tibbiye-i Şahane'nin Mekteb-i Tıbbiye-i Şahane'ye Getirdiği Eleştiriler (1857-1867)", Osmanh Bilimi Araştırmalan, C.III, S.1, İstanbul 2001, s. 20. 
nin maiyetinde olmak üzere de "Cemiyet-i Tibbîye-i Mülkiye" adında ayr bir heyet oluşturulmuştur. Bu heyete Mayıs 1840'ta kurulmuş olan Meclis-i Umûr-1 Tibbiye-i Mülkiye'nin rolü yüklenmiştir. Bütün bu düzenlemelerden sonra Osmanlı ülkesinde adlî tubba ilişkin şöyle bir yapı ortaya çıkmıştr: Başkent İstanbul'daki "Cemiyet-i Tıbbiye" adlî tup konularında en üst kontrol ve denetim organ konumuna yükselmiştir. Gerektiğinde yetersiz görünen tabiplerin görevlerinden alınabilmesi veya yerlerinin değiştirilmesi yetkisi Tıbbiye Cemiyeti'ne verilmiştir. Bu yapı 1904 senesine kadar devam etmiştir. 1904'te ise Nezâret-i Tibbiye-i Mülkiye yerine "Meclis-i Umûr-1 Tibbiye-i Mülkiye ve Sıhhiye-i Umumiye" kurulmuş ve kssa bir süre sonra ismi "Meclis-i Maarif-i Tıbbiye"ye tahvil edilmiştir. Bu kuruluş sivil sağlık ve belediyeyi ilgilendiren işlerde Dâhiliye Nezâreti'ne; askerî işlerde ise Umum-u Mekâtib-i Askeriye Nezâreti'ne bağh olmuştur. Bu kuruluş 1910 senesinde tekrar "Meclis-i Umûr-1 Tibbiye-i Mülkiye ve Sihhiye-i Umumiye", 1912 ylhndaysa "Cemiyet-i Tıbbiye-i Mülkiye" adını alacaktır. Oldukça karışı bir görünüm arz eden sağlık işlerine dair bu yapı içerisinden adlî tbbın çıkartılarak, bağımsız bir birime dönüştürülebilmesi ancak 22 Nisan 1917 tarihli kanunun 17. maddesiyle "Meclis-i Tibb-i Adlî ve Müessesesi"nin kuruluşuyla mümkün olabilmiştir. ${ }^{16}$ Aynı yl adlî tup Adalet Bakanlı̆g'na bağlanmış ve bakanlık bünyesinde Adlî Tıp Müessesi Müdürlüğü ve Meclisi kurulmuştur. ${ }^{17}$

\section{2) Uygulamada Otopsi}

Bu kurumsal oluşum ve dönüşümlerden sonra bazı örnek hadiseler üzerinden otopsi uygulamalan esnasında Osmanlı idaresince nasıl bir tavir takınıldığna dair bazı bilgiler sunmak, devletin otopsi hususundaki hassasiyetinin daha ìyi anlaşılmasına olanak sağlayacaktır. Óncelikli olarak belirtmek gerekir ki; birkaç istisna dışında adlî tup konusunda çizilmiş olan resmî, hukukî ve tubbî çerçevenin dişına gerek resmî görevliler gerekse halk tarafindan herhangi bir taşma hareketinin yaşanmasına katiyen müsaade olunmamıştır. Aksi bir durumla karşılaşılması halinde ise gereken yasal tedbirler süratle alınmış ve aynı şekilde de uygulama sahasına aktarılmıştır. Mesela görevlendirildiği halde otopsi ameliyatın icrada herhangi bir gecikmenin yaşanmasına sebebiyet vermek veya vazifeye itaatsizlik göstermek tabipler için görevlerine son verilmesi gibi bir yapturımla karşlaşmalan manasına gelmekteydi. Kalkandelen Belediye tabibi Mustafa Hilmi Efendi 1903 senesinde bunu çok acı bir şekilde tecrübe etmişti. Nitekim Hilmi Efendi, Kalkandelen'e bağh köylerden birin-

\footnotetext{
${ }^{16}$ Bingöl, a.g.m., s. 41-42.

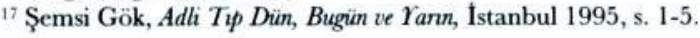


de öldürülen bir kıptinin cesedini keşif ve inceleme işini erteleyince hemen açı̆̆a alınmıştu. Tabip Efendi hadisenin ardından; ertelemenin keyfi olmadığına, o zamana kadar vazifesini laykkıla yerine getirdiğine, bundan sonra da bir dakika dahi mesaisini sarf etmekten geri durmayacağına, velhâsıl affedilmesine dair arzuhalini Rumeli Müfettişliği'ne sunmuşsa da artık çok geç kalmışt. ${ }^{18}$

Mustafa Hilmi Efendi görevini uygulamada gösterdiği gevşeklikten ötürü açı̆̆a alınmışken; sıradaki Osmanlı tabibi de hızlı davranmanın cezasını çekecekti. Şöyle ki Osmanlılar zamanında otopsi ameliyatlarının icra olunabilmesi için ölüm hadisesinin üzerinden 24 saat geçmesi gibi fennen kabul görüp, hukuken de hüküm altına alınmış olan bir uygulamanın mevcudiyetine rağmen Hanya memleket tabibi Wom'un giriştiği bir otopsi ameliyatı sırasında usule riayet etmemesi sebebiyle azledilmesi gerektiğine dair Meclis-i Tıbbîye-i Mülkiye'den bir açıklama yapılmıştı. ${ }^{19}$ Yine halk da gerekli adlî ve tubbî incelemeler gerçekleştirilmeden ölülerini defnedemiyordu. Mesela 1905 senesinde, Manastır kazasının Bukovo köyünde ölen Elini adındaki kızını gömmek üzereyken, pederine cesedin bir tabipçe incelenmeden defnedilemeyeceği haturlatılmıştı. ${ }^{20}$

Osmanl gibi çeşitli milletlerden müteşekkil bir imparatorlukta ve o milletleri imparatorluk mekanizmasıyla bir arada tutan bağların iyiden iyiye gevşediği, daha doğru bir ifadeyle gevşetildiği bir süreçte icra sahasına konulan bazı otopsi ameliyatları merkezî idareyi oldukça rahatlatan eylemlerden birisi olmuştur. Zira azınlıkları ilgilendiren bütün hadiselerde olduğu gibi onlanı şüpheli bir şekilde ölmelerinden de artık Osmanlı Hükümeti'nin mesul tutulduğu bir sürece girilmişti. Hal böyle olunca hükümet temsilcileri de haklı oldukları durumlarda çıkış yolunu otopsi ameliyatlarının icrasında bulmuşlardır. 1890 senesinde meydana gelen bir hadisenin akışında merkezî idareye söz konusu çıkışta rastlamak mümkün olmuştur. Nitekim o senenin 12 Ocak tarihine tesadüf eden Pazar günü Kaffafiyan Oseb Efendi'nin oğlu Aram Efendi, Damad Mahmud Paşa'nın kethüdası Salih Bey'in hizmetinde bulunanlardan birisi ile ayaküstü sohbet ederken birdenbire yere düşerek, oracıkta ölecektir. Olümün beyin inmesi (sekte- $i$ dimağ) ${ }^{21}$ kaynaklı olduğu ilk muayenesini gerçekleştiren tabip tarafindan ifade olunacaktır. Ardından Aram Efendi'nin cesedi defnedilmek üzere Beyoğlu'nda, Balıkpazarı'nda bulunan Ermeni kilisesine kaldırılmıştır.

${ }^{18}$ BOA, TFR.I.ŞKT, 5/478; 17 Zilhicce 1320/17 Mart 1903.

${ }^{19}$ BOA, DH.MKT, 1342/5; 7 Muharrem 1301/8 Kasim 1883.

${ }^{20}$ BOA, TFR.I.MN, 72/7161; 26 Cemaziyelâhir 1323/28 Ağustos 1905.

${ }^{21}$ Sekte-i dimağ veya beyin inmesi; beyin kan dolaşımındaki bir bozukluktan (kanama, tukanma vb.) ileri gelen koma ve felç durumudur. Bkz. Ekrem Kadri Unat-Ekmeleddin İhsanoğlu-Suat Vural, Osmanhica Tip Terimleri Sözlǚüu, Ankara 2004, s. 309. 
İşte tam bu noktada Osmanlı hükümeti ve yukarıda işaret olunan kaygı devreye girecek ve kimsenin ölümle ilgili herhangi bir itham ve yorumda bulunmaması için pederi Oseb Efendi'ye ceset üzerinde otopsi icra olunması teklif edilecektir. Teklifin kabul görmesinden sonra seçilen tabiplerle cesedin kaldırıldığı kiliseye gidilecek ve otopsi ameliyat gerçekleştirilecektir. Ameliyat sırasında ölünün beyninde ilk teşhisi doğrular bir alamet görülmemiştir. Aksine yüksek kan basıncından (tehacüm-ü dem) dolayı akciğerindeki büyük damarlardan birinin tkanarak nefesini kesmesi sebebiyle Aram Efendi'nin ölmüş olduğu tespit edilmiştir. Otopsinin ardından, pederini iknaya kâfi gelen bu tespitin diğer kimselerce de denilecek bir söz bırakmadığına dair bir açıklamada bulunma lüzumu hissedilmiştir. Bütün bu yaşananların ardından ceset kiliseden kaldırılarak Şişli'de bulunan Ermeni Kabristanına defnedilmiştir. ${ }^{22}$

\section{C- Osmanlılarda Otopsi Ameliyatlarn Nasıl İcra Edilirdi?}

Otopsi ameliyatlarıyla ilgili olarak Osmanlı Ceza Kanunu'nda şöyle bir ifade vardı: Birinin şüpheli bir şekilde hayatını kaybetmesi üzerine ölümün yaralama, boğma, boğulma, zehirlenme veya diğer hangi surette meydana geldiğini saptamak için bir savcı veya sorgu hâkimi huzurunda Osmanlı tabipleri marifetiyle otopsi ameliyatı icra olunur. ${ }^{23}$ Osmanlılarda otopsi ameliyatlarının ne şekilde uygulandığı$\mathrm{m}$ daha iyi anlayabilmek içinse o devirde gerçekleştirilen ameliyatlara ilişkin ayrıntı arz eden otopsi raporlarından birkaçını incelemek yerinde olacaktır. Bu ayrınthı raporlardan birisi Sivash Agop'a aittir. Agop'un otopsi ameliyatı bakteriyoloji laboratuarında ${ }^{24}$ yapılmıştır. 40 yaşlarında bir çiftçi olan Agop, 1894 senesi içerisinde Samsun'dan Gürcü kumpanyasına ait bir vapurla İstanbul'a getirilerek kaldırıldığı Yedikule Ermeni Hastanesi'nde ölmüştür. Ölümünün kolera tesirli olduğuna dair kimi şüpheler ortaya çlkınca cesedi üzerinde otopsi ameliyatı icra olunması lüzumu hâsıl olmuştur. Geç kalındığına dair tabipler arasında yaşanan oldukça sert tartışmalar arasında icra kılınan otopsi neticesinde ameliyata dair şöyle bir rapor hazırlanmıştr: ${ }^{25}$

22 BOA, Y.PRK:ZB, 5/21; 25 Cemaziyelevvel 1307/17 Ocak 1890.

${ }^{2}$ BOA, DH.HMS, 2/3-01; 11 Recep 1334/14 Mayıs 1916.

${ }^{24}$ Laboratuar, mektepte oğrenim gorren talebelere bakteriyoloji fennini uygulamalı olarak oğretmek uzere Tibbiye civannda tesis olunmuştur. Evvela İstanbul sularım tahlil etmek, sonra; sebze, meyve, et ve diğer erzakların görülen luzum üzere tetkiklerini gerçekleştirmek ve herhangi bir mahalde kolera, tifo ve kuşpalazı gibi hastalıklarla, hücre veya ruam gibi nadir hastalıklar ortaya çıktığında bunlan teşhis etmek laboratuarnn kuruluş gayesi olarak izah edilmiştir. (BOA, A.MKT.MHM, 563/13; 25 Şevval 1311/ 1 Mays 1894).

${ }^{25}$ BOA, 1.Mtr, 95/43; 4 Zilhicce 1311/8 Haziran 1894. 
Otopsisine ölümünden 45 saat sonra başlanılan Agop'un ilk bakışta güçlü bir bünyeye sahip olduğu ve bedeninin bazı bölgelerinde morluklar bulunduğu müşahede olunmuştur. Ardından tabip Koçoni tarafından gerçekleştirilen sondajla, tahlilleri yapılmak üzere vücudundan rengi koyu ve bulanık olarak 200 gr kadar idrar (bevl) çıkartılmıştur. Sondajdan sonra hastanenin tabiplerinden Kapril Efendi, cesedi, idrar kesesi civanndan başlamak suretiyle göğüs boşluğuna kadar yarmıştır. Bunun ardından iç organlann incelenmesine geçilecektir:

İç kaslar karaciğer (kebed) renginde, yani koyu kırmızı bir halde görülmüştür. Mide, karaciğer ve dalak (thâl) üzerinde kan toplanması (ihtikan) gibi herhangi bir anormalliğe rastlanılmamıştır. İnce ve kalın bağırsaktan (em'â-i rakika ve galiza) alınan parçalar da tahlil olunmak üzere bir şişeye konulup, mühürlenerek Tibbiye Mektebi'ne gönderilmiştir. Aynca mide kısmen gaz kısmen de sıvı ile dolu bir vaziyette bulunmuştur. Böbreklerden (kilye) birisiyle karaciğerden alınan bir parça da ayrı birer şişeye konulup söz konusu mektebe gönderilmiştir. Kalın bağırsağın tortu kısmında ise açık renkte bir sıvıya rastlanılmıştır. Ayrıca ince ve kalın bağırsağın birer parçası açılıp yıkandığında bağırsak zarının üzerinde kan toplandığı görülmüştür. Ancak herhangi bir yaraya tesadüf olunmamıştır. Kalp çıkarılarak yarıldıkta birkaç küçük kan pıhtısından (alakat) başka kayda değer bir şeye tesadüf olunamamıştır. Beyin dahi yanlıp incelendiğinde doğal halinde bulunmuş, yine böbreklerden birisi çıkanlıp yarıldıkta hakikî bir kan toplanması ile karşılaşılmamıştır. Alınan parçaların tahlilleri gerçekleştirildikten sonra da ölüme dair kesin teşhisin konulacağı ifade olunarak Agop'un cesedi Baklahı'da bulunan kabristana defnolunmuştur. ${ }^{26}$

Ameliyatların icrasında nasıl bir yol izlendiğine ve kimlerin hazır bulunduğuna dair bir diğer ayrıntılı raporsa Hanya Liman Reisi Sami Kaptan'a aittir. Sami Kaptan 1883 yılında, 40 yaşındayken ölmüştür ve yine kolera şüphesiyle cesedi üzerinde otopsi ameliyatı icra olunmuştur. Sami Kaptan'a otopsi uygulayan Hanya memleket tabibi Wom tarafından hazırlanan otopsi raporundaysa şunlar kayıthdır:

20 Temmuz'da ölen Sami Kaptan'ın otopsisini icra etmek üzere ölümünden üç buçuk saat sonra ve saat üç buçuk sularında hanesine gidilmiştir. Bir savcı, bir imam, bir müezzin ile İslam ahalisinden bazılarının yamı sıra ${ }^{27}$ karantina tabibi Daston'a vekâleten tabip Mösyö Nikolaindi ve zabıta memurları otopside hazır bulunmuşlardır. Haneye varıldığında ceset; çarşafla örtülü, ayaklan ve çenesi men-

${ }^{26}$ BOA, Y.PRK.ȘH, 4/83; 22 Şevval 1311/28 Nisan 1894.

${ }^{27}$ Bugünün anlayışına göre yetkisiz ve gereksiz kişilerin otopsi sırasında hazır bulunmalanna izin verilmemektedir. Bu sayede temelsiz iddiaların yanısıra yanlı̧ yorumlama ve anlama olasılığ da azalmaktadır. Bkz. Soysal-Eke-Çağdır, a.g.e., s.101. 
dille bağh ve kıbleye yöneltilmiş bir vaziyette görülmüştür. İlk bakışta kaptanın, sağlğ̆inda kanlı bir mizaç ile kuvvetli azalara sahip birisi olduğu müşahede olunmuştur. Ardından karın boşluğu yarılmıştır. İç organlarında tıbba aykın herhangi bir emare müşahede olunmamıştr. Lakin sadece ince bağırsağın içerisinde oldukça koyulaşmış bir vaziyette kan toplanmış olduğu görülmüştür.

Yine göğüs boşluğu (cevf-i sadri) muntazam bir halde bulunduğu gibi akciğer (rie) ve yürekte de herhangi bir şüphe alametine rastlanılmamıştır. Aynı şekilde, yarılan kalp içerisinde tbben olumsuz bir durumla karşılaşılmamıştr. Kalp damarları (unuk-u kalb) ile zan (gŗ̧â'-i kalb) arasındaki mahal de her bir hastalıktan salim olduğu gibi, söz konusu mahalde sıvı bir maddenin (mevad-ı saile) toplanmadığı görülmüştür.

Son olarak, bir testere vasıtasıly yuvarlak bir şekilde açılan kafatasının (kihf) içini dolduran siyah kanın büyük bir kısmı akmıştır. Bundan sonradır ki Sami Kaptan'ın koleradan değil, beyninde şiddetli kan toplanmasından ölmüş olduğu kanısına varılmıştır. Ayrıca uyuşturucu bir maddenin cilt altına konulmasından dolayı basıncın şiddetinin artmış olduğu da ilave olunmuştur. ${ }^{28}$

Ameliyatlar icra olunduktan sonra sıra otopsilere ait raporların hazırlanmasındadır. Son örnekte daha açık bir şekilde görüleceği üzere rapora; otopsinin nerede, ne zaman, kimlerin huzurunda ve kim tarafindan yapılmış olduğuna dair bilgilerle başlanır. Bundan sonra uygulanan işlemler tek tek sıralanır. Sonuç kısmında ise eğer netleşmişse ölüm sebebi nakledilir, ayrıca tesadüf edilen belirtilerden yola çıkılarak ölüme dair bazı yorumlara yer verilir. ${ }^{29}$

Görüldüğü üzere her iki otopsi ameliyat sırasında kafa, göğüs ve karın boşluğu denilen üç boşluk da açılmıştır. Bugün de CMUK'un 81.maddesi uyarınca her üç boşluğun açılması gerekmektedir. Bu boşlukların açılma sırası yoktur. Hekim istediği boşluğu açarak otopsiye başlayabilir. Ancak bugün daha ziyade kafa boşluğunun açılması suretiyle başlanılan ${ }^{30}$ otopsi ameliyatlanı Osmanlı hekimlerince bunun tam tersi bir istikamette icra olunmuştur. Burada hemen ifade etmek gerekir ki; teknolojik gelişmeler dişarıda tutulacak olursa Osmanlılar döneminde uygulan otopsi ameliyatları ile bugünküler arasında çok büyük farklılıklar yoktur.

${ }^{28}$ BOA, DH.MKT, 1342/5; 7 Muharrem 1301/8 Kasım 1883.

29 Otopsi raporlarının bugün ne şekilde hazırlandıkları ile ilgili oldukça aynntılı bilgi ve örnek raporlar için bkz. İssan Sarıkardaşoğlu, Adli Tipta Ana Komular ve Ömeklerle Rapor Yazma Tekniği, Eskişehir 1990, s.22-78; Orsal-Katkaci, a.g.e., s. 27-51.

${ }^{30}$ Gök, a.g.e, s.38; Otopsilerin bugün nasıl bir ortamda ve ne şekilde icra olunduğu ile ilgili olarak bkz. Oztürel, a.g.e., s.224-231; Oğuz Polat-Mehmet Akif İnanıcı-Mustafa Ercüment Aksoy, Adli Tip Ders Kitabr, İstanbul 1997, s.31-41; I.Hamit Hanci, Adli Tip ve Adli Bilimler, Ankara 2002, s. 308-309. 


\section{D- Osmanlılar Döneminde İddialar ve Otopsi}

Otopsi sayesinde ölümü meydana getiren unsurlara, kimliğe ve varsa sanıklar hakkında önemli detay bilgilere ulaşlabilmekte ve dolayısıyla adaletin doğru bir şekilde ve zamanında yerine getirilmesi sağlanabilmektedir. Ölüm nedeniyle ilgili olmayı, rastlantı sonucu bulunan ve önemsiz ayrıntı gibi görünen bir bulgu, olayın orijininin (intihar, kaza, cinayet, doğal) belirlenmesinde çok önemli olabilir. Bu bulgu ile ölümün nasıl, neden ve nerede meydana gelmiş olduğu belirlenebilir. Otopsi sayesinde ölüm nedenine ait kuşkular ile olgu hakkındaki gereksiz tahminler de ortadan kaldırılmış olur. Otopsi ile gerçek ölüm nedeni ve şeklinin belirlenmesi, ileride ortaya çıkabilecek sorunların aşılmasına ve soruların da cevaplandırılmasına olanak sağlar. ${ }^{31}$

İşte çalışmanın bu kısmında, incelenen 40'a yakın ölüm vakası; iddia ve şüphelerin yanında otopsi ameliyatından sonra ortaya çıkan kesin neticeler açısından ele alınmak suretiyle Osmanlı adlì tubbının söz konusu ölümlere dair şüpheleri ortadan kaldırma ve adaleti temin etme noktasında otopsi ameliyatlarından ne ölçüde istifade etmiş olduğuna dikkat çekilmeye çalışlacaktır. Ancak hemen şunu da üzülerek ifade etmek gerekir ki incelenen bütün otopsi ameliyatlarının ayrnntlı raporlarına ulaşmak mümkün olamamıştır. Daha da kötüsü; resmî makamlar arasında gerçekleşen yazı̧̧malarda otopsilere ait bir raporun mevcudiyetinden bahsediliyorken çoğu kez ilgili vesikalar arasında onlara tesadüf etmenin mümkün olamayışı; ölene, ölüm sebebine ve otopsi ameliyatunı içeriği ile neticesinde ortaya çıkan görüntünün ölümle ilgili şüphe bulutların dağtacak bir netliğe sahip olup olmadığına dair bilgilerden mahrumiyeti de beraberinde getirmiştir. Mesela 1908 senesinin Kasım'ında Zaptiye Nezareti'nden Beykoz Savclığı'na çekilen bir telgrafta Anadolu Hisarı civarında sakin olan Ömer Efendi'nin ölen hanımının otopsi ameliyatının gerçekleştirildiğine dair Etibba Dairesi tarafindan tanzim olunan bir raporun kendilerine gönderilmiş olunduğundan bahsedilmişse de söz konusu rapora ulaşılamamışurur. ${ }^{32}$

\section{1) Darp ve Otopsi}

İncelenen otopsi ilintili ölüm vakalarından beşinin darp tesiriyle vukua geldiği iddia olunmuştur. Darba maruz kaldığı iddia edilenler arasında iki aylık bir bebe$\breve{g i n}^{33}$ de bulunuyor olması oldukça esef verici olsa gerektir. Darp etmekle itham olunanlardan üçünün resmî görevliler olması ise dikkat çekicidir. Bunlardan birisi

\footnotetext{
Soysal-Eke-Çağdır, a.g.e., s. 7-14.

i2 BOA, ZB, 492/3; 2 Kanunuevvel 1324/15 Aralık 1908.

BOA, DH.MUI, 43-I/II; 12 Zilhicce 1327/25 Aralık 1909.
} 
Mirliva Sadık Paşa'dır. Onun tarafindan maruz kaldığ darbın tesiriyle öldüğü iddia edilen İsmail isimli şahıs, neticesinin ne olduğuna dair herhangi bir bilgiden yoksun kalınan otopsi ameliyatundan ve ameliyata dair raporun da Zaptiye Nezâreti'ne ${ }^{34}$ tesliminden sonra sessiz sedasız bir şekilde Üsküdar Kabristanı'na defnedilmiştir. ${ }^{35}$ Lakin darp tesiriyle öldükleri iddia edilen şahıslardan diğer ikisinin Gayrimüslim tebaadan olmalan ise tarihinin son köşe başını tutmuş olan I.Dünya Savaşı arifesinde ve içerisinde en sıkıntılı demlerini yaşayan imparatorluk idaresini haylice zor bir durumda bırakmıştur. Üstelik idarî birimlerce bütün örtbas etme gayretlerine karşın ölenlerin darp edildiklerine dair iddiaların haklılık yanlarının ağır basması merkezî idarenin işini bir kat daha zorlaşturmıştır. Osmanlı bürokrasisini terleten otopsi ameliyatlarıyla alakalı söz konusu gelişmeler hadiselerin seyri dikkatli bir şekilde takip edilince daha iyi anlaşılacaktır:

Bu hadiselerden ilki 1913 senesinde, Muş Sancağı'na bağlı Dartenis köyünde yaşanmıştır. İddiaya göre köyün davulcusu olan Milo adındaki Ermeni, Jandarmalarca maruz kaldığı darbın tesiriyle ölmüştür. Bunun üzerine bölge adliyesince başlatılan tahkikat kapsamında bir sorgu hâkimi, bir savcı muavin vekili ve bir de zabıt kâtibinin hazır bulunduğu sırada belediye tabibi tarafindan Milo'nun cesedi üzerinde otopsi ameliyatı gerçekleştirilmiştir. Otopsi neticesinde davulcunun akciğer zarı iltihabından (zât-ül-cenb hastalı̆ından) ölmüş olduğu ortaya çıkanlmıştır. Ancak bölgedeki Ermeni Murahhası olan Nersisi Efendi otopsi neticesini doğru bulmayacaktır. Murahhas Efendi'ye göre Milo mültezim ambarının sevki sırasında jandarmalarca maruz kaldığı darptan dolayı 10 gün süren keyifsizliğin ardından ölmüştür. Muş Mutasarrıflğ'na göreyse Murahhas Efendi bir yalancıdır. Çünkü davulcu köyün en fakiridir. Dolayısıly ne sevk edecek zahiresi ne de bir sevk hayvanı vardır. Murahhas Efendi böyle davranarak ahaliyi hükümetten ziyade sahiplendiğini gösterme gayreti içerisindedir. Muş Mutasarnflığı'nın açıklamalarını inandıııcı bulan Bitlis Valiliği tarafindan, olayın tekrardan tahkikini isteyen Dâhiliye Nezâreti'ne bu tür sorunların insanları birbirine düşürmek için sağdan soldan esen bir cereyanın mahsulü olduğuna dair bir izahatta bulunulmuştur. Dâhiliye Nezareti ise her ihtimale karşın bu meselenin de diğerleri gibi Istanbul'daki Ermeni gazetelerinden birinde çarpıttlmış vaziyette neşredilme ihtimalini göz önünde bulundurarak, böyle

34 1879 senesinde, Zaptiye Nezareti bünyesinde de bir Zâbıta Tababeti Adliye Şubesi kurulmuştur. Bu şubeye tayin edilen hekimler şimdiki adlî tabiplerin yaptı̆̆ işlere bakmışlardır. Bkz. Gök-Ozen, a.g.e, s. 3 .

${ }^{35}$ BOA, ZB, 479/28; 23 Eylül 1323/6 Ekim 1907. 
bir haberle karşılaşıldı̆ğ takdirde tekzip edilmesi için Matbuat İdaresi'ne bir uyarıda bulunacaktır. ${ }^{36}$

Otopsi ameliyatı adeta bir devlet meselesi haline dönüşen darp iddialı bir diğer ölüm vakası da 1915 senesinde İzmir'de yaşanmıştır. Maruz kaldığı darbın tesiriyle öldüğü iddia edilen Vasil ismindeki şahıs ise Rum milletindendir. Yunan sefaretinin de müdahil olmasıyla içinden çıkılmaz bir hal alacak olan hadise; İzmir'de bir bakkal dükkânı işleten Vasil'in bir hırsızlık olayından dolayı zanlı olarak bölgedeki polis memurlarınca tutuklanmasıyla başlamıştır. Akrabalanının iddialarına göre, Vasil gözaltı süresince şiddetli bir şekilde darba maruz kalmış, ardından sevk olunduğu hapishanede de her gün işkence görmüştür. Bu kadar işkenceye de dayanamayarak, ölümünden bir gün evvel kaldırıldığı Gureba Hastanesi'nde hayatını kaybetmiştir. Onun ölümünün darp kaynaklı olduğuna ilişkin akrabalarında şüphe uyandıran gelişmeler ise şunlar olmuştur: Evvela gerek hapishane gerekse hastane memurlan akrabalarının Vasil'i uzaktan görmelerine dahi katiyen müsaade etmemişlerdir. Hatta vekâletnamesini hazırlamak için yanına varan adliye kâtibine dahi gösterilmemiştir. Ölümünden sonra da şehrin Tepecik Mahallesi'nde bulunan bula\$̧ıcı hastalıklar hastanesine nakledilmiş ve orada ölenler hakkında eskiden beri uygulanmakta olan usullere uygun olarak hemen defnedilmiştir. Defin sırasında hazır bulunan Papaz Efendi'nin de Vasil'in tifo hastalığından ölmüş olduğunu ifade etmesi akrabalarına inandırıcı gelmemiş ve yaşananlardan İzmir Yunan Konsolosluğu'nu haberdar etmek suretiyle kendilerine devletçe tazminat ödenmesi taleplerini dile getirmişlerdir. Bunun üzerine konsolosluk tarafindan Hariciye Nezareti'ne; akrabaların söz konusu taleplerinden başka ölüm vakasına dair hakikatin gün yüzüne çıkartılması için ceset üzerinde otopsi icra olunmasına, ameliyat sırasında kendileri tarafindan tayin olunacak bir tabibin de hazır bulundurulmasına dair bir bildirimde bulunulmuştur.

Ancak yaşanan ve daha evvel yaşanmış olan şu gelişmeler Yunan konsolosluğunu da akrabalarla bir düşünmeye itecektir: Aydın Valiliği'nce icabının icrasına hemen girişileceğine dair bulunulan vaade rağmen otopsi ancak bu bildirimden altıyedi gün sonra uygulanmıştır. Ustelik ameliyata ve neticelerine dair konsolosluğa resmî bir tebligatta bulunulmadığı gibi, konsolosun daha evvelki isteğine uygun olarak ameliyatta Yunanlı bir tabibin de hazır bulundurulmasına dair herhangi bir gelişme yaşanmamıştır. 26 yaşında olan Vasil'in gözaltına alındığı tarihe kadar zinde ve sağlıklı bir vücuda sahip olduğu, morfin ve benzeri bir maddeye bağımlılığının da

3. BOA, DH.H, 15/10; 5 Mart 1329/18 Mart 1913. 
bulunmadığı saptanmıştur. Ayrıca ölümüne kadar hapishanede bulundurulması ve sadece ölümünden birkaç saat evvel hastaneye nakledilmesi Vasil'in tutuklu bulunduğu süre zarfinda bulaşıcı bir hastalığa yakalanmış olması ihtimalini bertaraf etmektedir. Çünkü Papaz Efendi'nin beyan ettiği gibi Vasil tifo hastalığına tutulmuş olsaydı günlerce hapishanede alıkonulmak yerine hemen doğrudan bulaşıcı hastalıklar hastanesine nakledilirdi. Son olarak Vasil'in akrabalan ile adlîye kâtibine gösterilmemesi ve cenazesinin sürat ve telaşla kaldırılmış olması da göz önünde bulundurulunca ölümün darp ve işkence tesirli olduğu açıkça ortaya çıkmaktadır. Şimdi, Yunan sefaretinin Babıâli'den isteği Vasil'in ölümüne sebep olanların cezalandırılmaları ve ailesine tazminat ödenmesidir.

Yunan sefaretinin bu israrcı tutumundan sonra hemen ortaya çıanlan otopsi raporunda ise şunlar kayıthdır: Divan-ı Harbe bağhı Eğin Gureba Hastanesi'nde ölüp, 12 Eylül'de defnedilen Vasil'in ölüm sebebinin kesin olarak tayini için ölümünden 4 gün sonra, yani 16 Eylül tarihinde, saat 12.00 civannda İzmir Divan-1 Harp savclanndan Hasan Fehmi, tahkik heyeti reisi Rufat Bey, Kemer Polis Karakolu Komiser Muavini Yusuf Ziya Efendi, Süvari Polislerinden Refik Efendi ve İzmir Belediye Tabibi Mehmed Ali Beyle birlikte Tepecik'teki bir kilisenin avlusunda bulunan kabre varılmıştır. Mezarcı tarafindan gösterilen kabir açturlıp, ${ }^{37}$ ceset tabutuyla beraber dişanya çıkartılmıştur. Ceset kefenden ayrıldıktan sonra gerçekleştirilen dış muayene neticesinde Vasil'in yaklaşık 35 yaşlanında ve orta ölçekli, zayıf bünyeli ve buğday renginde bir vücuda sahip olduğu kayıt altına alınmıştır. Kokmaya başlamış olan vücudunun dış kısmında darbe dair herhangi bir belirtiye rastlanmamıştır. Dış muayeneden sonra otopsi ameliyatına girişilmiştir. Otopsi sırasında iç organların da gayet sağlıkh bir vaziyette bulunduklan görüldükten sonra nihayet Vasil'in hapishanede duçar olduğu lekeli humma (tifus-i nemeşî) hastalığından öldüğü ortaya çıkmışur.

Sira hazırlanan raporun sert ifadelerle Yunan sefareti tarafina takdimine gelmiştir. Öncelikli olarak, konsolosun bu gibi meselelere herhangi bir müdahalede bulunma gibi bir hakka sahip olmadiğına dikkat çekilirken sadece yanlış anlaşılma-

${ }^{37}$ Mezar aģmalar (feth-i kabir), en sıklıkla, ailenin isteği doğrultusunda veya mezarlığın kapatılması veya yerinin değıştirilmesi gerektiğinde söz konusu olur. Bazen, ilk otopsinin tekrarlanması gerekebilir. Bu genelde, ölümün gerçek nedeni hakkanda birtakım kuşku ve iddialann gündeme geldiği durumlar için söz konusudur. Feth-i kabir sonucu elde edilen bulgular, her ne kadar taze bir cesetten elde edilenler kadar doyurucu olmasa da, oldukça uzun bir gömü süresinden sonra da bunlardan değerlendirmeye uygun veriler elde edilebilir. Çürüme hızı büyük değişiklikler gösterir; buna karşın aylar ve hatta yıllar sonra da, feth-i kabir ile çıkanlan ceset üzerinde değerlendirmeye uygun bir otopsi yapma olanağı vardır. Bu hususla ilgili daha fazla bilgi için bkz. Cedric Keith Simpson, Adli Tip, Ed. Bernard Knight, Istanbul 1995, s.32 (Bu kitap editörlüğünü Dr. Nur Birgen'in yaptığı bir ekipçe Türkçe'ye tercüme edilmiştir). 
lan ortadan kaldırmak için otopsi ameliyatının gerçekleştirildiği ifade olunmuştur. Kendilerine sunulan rapor ve zabıt varakasının içeriğinden de anlaşlacağı üzere Vasil, Yunan sefaretinin iddia ettiği gibi ne 26 yaşındadır, ne de sağlıklı bünyeye sahip birisidir. Kendisinin ölürken 35 yaşlarında olduğu ve ölümcül bir hastalı̆̆a tutulduğu saptanmıştır. Otopsi sırasında yabancı birisinin varlığına ihtiyaç duyulmadığından konsolosluktan tabip talebinde bulunulmamıştır. Nihayet iddiaların aksine Vasil'in hapisteyken yakalandığ lekeli humma hastalığından öldüğü de gün yüzüne çıkmıştr. Dolayısıyla Vasil'in ne karakolda ne de hapishanede darp edilme gibi bir hadise ile karşılaşmış olması söz konusu olamaz. ${ }^{38}$ Bu açıklamalar elbette konsolosluğun Yunan tarafinı haklı çıkarmak için sıralamış olduğu iddiaları çürütmeye yetecek nicelik ve nitelikten, dolayısıly inandırncılıtan uzaktur. En basitinden Vasil lekeli humma hastalı̆ından ölmüssse cesedinin ilk defni sırasında Papaz Efendi de dâhil herkesin ölüm sebebi olarak Tifo hastalı̆ı üzerinde yapmış oldukları ağız birliği nasıl oluyor da otopsi ameliyatından sonra tamamiyla farkh bir mecraya kaydırlabiliyor? Dolayısıly dönemin askerî ve siyasî atmosferinden kaynaklanan endişeler otopsi raporunun hazırlanışı sırasında tesirini fazlasıyla hissettirmiş olmalıdır. Yoksa 1916 senesinde Osmanlı ülkesinde ölen Alman bahriyesine mensup Dams'n Alman tabipleri tarafindan gerçekleştirilen otopsi ameliyatına mantıklı bir zemin bulmak oldukça zor olacaktur: Dams, Tarabya'da, Kalender civarındaki bir bahçede arkadaşlarıyla birlikte alkol alıyor, sonra aralarında baş gösteren kavga sırasında bostan kuyusuna düşerek ölüyordu. Cesede otopsi uygulanması söz konusu olunca Osmanh tabiplerinin sadece şahit ssfatylla bulundurulacağı ameliyatın Alman tabiplerince icra kılınması yönündeki Alman tarafinın isteği, bunun mevcut duruma muhalif bir hareket olduğunun üstüne basa basa kabul ediliyordu. Ustelik Alman askerinin imparatorluk ordusuna hizmet amaciyla Osmanlı ülkesinde bulunuyor olmasından dolayı buna herhangi bir itirazda bulunulmadığı da açıkça ifade edilmişti. ${ }^{39}$

\section{2) Zehirlenme ve Otopsi}

Zehirlenme kuşkusu bulunan ölüm olaylarında şahsın gerçekten zehirlenip zehirlenmediğinin, zehirlenmişse toksik maddenin cinsinin tespiti yapilacak otopside alınacak olan numunelerin analizinden sonra mümkün olur. ${ }^{40}$ Bugün $^{41}$ olduğu gibi

${ }^{38}$ BOA, DH.EUM.3.Şb, 10/57; 13 Safer 1334/21 Aralık 1915.

${ }^{39}$ BOA, DH.HMS, 2/3-01; 11 Recep 1334/14 Mayss 1916.

${ }^{40}$ Soysal-Eke-Çăgdır, a.g.e., s. 3-108.

${ }^{41}$ CMUK'un 89.maddesi zehirlenme şüphesi olan hallerde yapilacak işlemlerle ilgilidir. Bkz. Yasemin Balca, Herkes Iş̧in Adli Tip Cep Kitabı, Eskişehir 2008, s. 111. 
Osmanllar döneminde de zehirlenme iddiasıyla girişilen otopsi ameliyatlanının neticeye ulaşturılmasında Kimyahaneler önemli bir rol üstlenmiştir. Osmanlılarda otopsi sırasında ölünün çıkanlan iç organlanı ( $a$ ḩ̧̧ấ-i dahiliye) birkaç kavanoz, çömlek, şişe veya vazo içerisine konulur, ağılan da Etibba Dairesi mührüyle mühürlenmek suretiyle tahlil harçlan olan 5 mecidiye ${ }^{42}$ ile birlikte görevli memura teslim edilerek Kimyahane'ye gönderilirdi. Ayrıca zehirlenmeye sebep olduğu iddia edilen hâlihazırdaki maddelerin de kesin neticeye ulaşılabilmesi için Kimyahane'ye gönderilmesi elzemdi. Bugün ise cesetlerden alınan parçaların laboratuarlara gönderilmesi aşamasında 4 kavanoz ve iki şişeden istifade olunmaktadır. Temizlenmiş kavanozlardan birincisine karaciğerden, böbrekten ve dalaktan parçalar; ikincisine mide ve muhteviyatı ile bağırsaktan parçalar; üçüncüsüne beynin hepsi ve son kavanoza ise akciğerden parçalar ve kalp konulmaktadır. Şişelere gelince; birisine kan, diğerine de kavanoz içine konan tespit solüsyonu yerleştirilir. ${ }^{43}$ Osmanlılar da cesetten alınan iç organ numunelerini benzer bir tasnifle ve kavanozlar içerisinde Kimyahane'ye göndermekte ise de şişelerdeki kan ve tespit solüsyonundan istifadeyle tahliller yapmak ve bu sayede zehirli maddenin cinsini ve ölümle ilişkisini ortaya çıkarmak gibi bir gelişme gözlemlenememiştir. Ancak şurası kesindir ki; Osmanlı Kimyahanesi'nde zamanına göre ileri seviyede denilebilecek, detayl kimyasal ve fizyolojik incelemelerle analizler yapılmıştur.

Bu çalışmaya konu olan otopsi ameliyatlarının büyük bir kısmı zehirlenme iddiası ile icra sahasına aktarılmıştır. İddiaların büyük bir kısmı da içilen bir ilaca veya tüketilen bir yiyeceğe dayandırılmıştır. Mesela 1905 senesinde, Üsküdar'da Bulgurlu Mescid Mahallesi'nde ikamet eden Kemal Efendi'nin zevcesi Ayşe Hanım'ın yediği yiyeceklerden dolayı zehirlenerek öldüğü iddia edilince girişilen otopsi ve Kimyahane tahlilleri neticesinde vücudunda 2 santigram kadar cıvadan ${ }^{44}$ başka mide ve idrar kesesinde (mesâne) zehre dair herhangi bir maddeye tesadüf olunamamıştur. ${ }^{45}$ Aynı şekilde İranlı Süleyman adlı şahısça imal olunan bir ilacı içtiği günün ertesi öldüğü iddia edilen Lazari adlı şahsın yapılan tahliller neticesinde vücudunda herhangi bir zehirli maddeye rastlanmadığı Kimyahane memurlan tarafindan bildirilmiştir. ${ }^{46}$

\footnotetext{
${ }^{42}$ Düstur'da yayınlanan keşfiyât ve tahlilât tarifesinde, bu tür tahlilin ücreti 5 mecidiye gösterilmiştir. Bkz. Bingöl, a.g.m., s. 44.

${ }^{+3}$ Gök, a.g.e., s. 39.

${ }^{44}$ Civanın zehirleyici dozu; genel olarak $0,2-1 \mathrm{gr}$ olarak kabul edilmekle beraber, bunda vücut yapısının rolü de çok önemlidir. Bkz. Ibrahim Tunali, Adli Tip, Ankara 2001, s. 244.

${ }^{45} B O A, Z B, 302 / 39 ; 30$ Temmuz 1321/12 Ağustos 1905.

${ }^{46} B O A, Z B, 40 / 99$; 1 Teşrinisani $1323 / 14$ Kasım 1907.
} 
Kimyahane'de ne tarz tahlillerin yapıldığına dair bir iki misalle konuyu zenginleştirmek gerekir. Mesela, 1903 senesinde Karamürsel'de sakin Bosnalı Hacı Ali Efendi'nin bakkaldan aldığı müshil haplarının kullanımını müteakip zehirlenmesi üzerine girişilen otopsisi sırasında midesinden çıarılan 184 adet hap tanesi Kimyahane'de inceleme altına alınmıştı. Hangi maddeden mamul olduklarını anlamak için birkaçı kesildiğinde, hapların kokusuz ${ }^{47}$ ve pek acı olmalarının yanı sıra beyaz, kırmızı ve san renkteki toz tanelerinden müteşekkil bir hamurdan imal edildikleri anlaşılmıştır. Tahlili yapılan hap hamurunun da nişasta hububatından başka sarısabır otundan ${ }^{48}$ mamul tozla, anason ve kırmız böceği tozlarının bileşiminden imal edilmiş bir karışım olduğu saptanmıştır. Hamurundan çıkarılan 15 santigram kadar sarısabır otundan başka, ne haplarda ne de iki kavanoz içerisinde Kimyahane'ye gönderilen vücudun iç organlannda ölüme sebep olacak başkaca bir zehirli maddeye tesadüf olunamamıştır. ${ }^{49}$

Osmanlı Kimyahanesi'nde, otopsi kapsamında sıvı maddelerin tahlilleri de yapılmak suretiyle ölüm vakasının hangi sebepten kaynaklandığı saptanabilmiştir. Mesela, Silivri kuyusu civarında bulunan Hancı Karagöz mahallesinde zehirlenerek ölen Razı adlı çocuğun otopsi ameliyatından sonra alınarak, iki vazo içerisinde Kimyahane'ye gönderilen mide ve bağırsaklan (ema) ile diğer iç organları arasındaki sıvının, fenni usullere uygun olarak gerçekleştirilen tahlil neticesinde arsenikten ${ }^{50}$ başka bir şey olmadığı ortaya çıkarılmıştı. ${ }^{31}$

Katı veya sıvı maddeler üzerinden gerçekleştirilen tahlillerle, ölümlerin zehirlenmelere bağlı olarak meydana gelip gelmedikleri konusunda kesin neticelere ulaşma noktasında Osmanlı Kimyahanesi'nin oldukça başanılı bir çizgide bulunduğunu söylemek yanlış olmasa gerektir. Belki de bu çizgiyi koruma çabasındandır bilinmez; bazen Kimyahane memurlan ile otopsi ameliyatlanını gerçekleştiren ta-

${ }^{47}$ Otopsi ameliyatlannda kokunun kendine has bir kıymeti vardır. Keskin amonyak kokusu şahsın üremiden ölduğünü, sanmsak kokusu fosforla zehirlendiğini, acıbadem kokusu da asit siyanidrik veya siyanürlerle zehirlenerek öldüğünü akla getirir. Bkz. Gök, a.g.e., s. 38.

${ }^{+}$Sansabu otu; Müshildir, ancak fazla kullamilırsa diyareye neden olabilir. Midevidir; sindirimi kolaylaşturır. Safra söktürücüdür. Sarısabır aynca yaralan, küçük yanıklan, güneş yanıklanı ve böcek sokmalann ivileştirir. (http://wuere.ebithi.com adresinden 25.07.2010 tarihinde erişilmiştir).

${ }^{49}$ BOA, ZB, 301/41; 21 Haziran 1319/4 Temmuz 1903.

w Arsenik; toz halinde, organik ve anorganik birçok bileşikleri bulunan madensel toksik bir maddedir. Doğada ender olarak saf, daha çok diğer maddelerle birleşik halde bulunur. Arseniğin zehir gücünün yüksek olması, tedavisi için kullanılacak bir ilacın bulunmayış, belirtilerinin besinlerle meydana gelen mide, bağırsak bozukluklanna benzemesi dolayısıyla uzun süre bu zehirlenmeler fark edilememiştir. Tarih boyunca cinayetlerden başka, alınan ilaş ve besinler yoluyla zehirlenmelere ve ölümlere sebep olmuştur. Bkz. Ozturel, a.g.e., s. 349-351.

BOA, ZB, 302/33; 3 Ramazan 1321/23 Kasım 1903. 
bipler arasında kimi sıkıntıların yaşanmış olduğu da gözlemlenmiştir. Mesela, Mehmet adındaki bir çocuğun kendisine içirilen ve içeriğinde morfin bulunan 3,5 kaşık şurubun tesiriyle öldüğü şüphesi üzerine girişilen otopsi ameliyatını icra eden tabiplerce hazırlanan raporun istenilen bütün ayrıntlan kapsıyor olmaması Kimyahane memurlanının tepkisine sebep olmuştur. Bu tepkiyi çocuğun tahlil neticeleriyle ilgili olarak hazırlamış olduklan rapordan sezinlemek mümkündür. Raporda evvela; 3,5 kaşık, yani 5,5 gram şurupta 1,5 miligram oranında morfin bulunduğu, ancak çocuğun hiçbir organında morfine rastlanılmadığı kaydedilmiştir. Ardından bu halin çocuğun afyonlu şuruptan içmediği, yani ölümün şuruptan kaynaklanmadığı anlamına gelmeyeceğine, aynca ölüm sebebinin tam olarak aydınlığa kavuşturulması için tesirli maddenin cins ve miktarının tayin edilmesinin de yeterli olmadığına dikkat çekilmiştir. Kesin neticeye ulaşabilmek, ancak çocuğun sağlık durumu ile afyona olan bağımllık derecesinden başka otopsi esnasında organlar üzerinde görülmüş olan izlerin ne anlam ihtiva ettiklerinin de bilinmesi ile mümkündür. Dolayısıyla söz konusu hususlanı netleştirmenin otopsiyi uygulayan tabiplerin hazırlayacakları daha ayrıntılı raporlarla mümkün olacağı ifade edilmiştir. ${ }^{52}$

Bunlardan başka Osmanlılar döneminde zehirlenme şüphesiyle otopsi ameliyat icra olunan ölüm vakalarıyla ilgili olarak oldukça farklı, bir o kadar da ilginç iddialar ortaya atılmıştır. 1903 yılı kışında Tikveş'in Çarşı Mahallesi'nde ikamet etmekte olan Hüseyin kızı Ayşe böyle ilginç bir iddiayla mahkemeye başvurmuştu. Ayşe Hanım, pederi Hüseyin Ağa'nın nakit paradan müteşekkil olan servetine sahip olabilmek ümidiyle yakın akrabalarınca zehirlenerek öldürülmüş olduğu ve 4.000 lira civarındaki nakdinin de katillerce gasp edildiği iddiasındaydı. Bunun üzerine babasının cesedine otopsi uygulanmış ve iç organları da zehirlenme şüphesinde gerçeklik payı olup olmadığını gün yüzüne çıkarmak için kasabanın bağh olduğu vilayetin Kimyahanesi'ne gönderilmiştir. Ancak Kimyahane tarafindan hazırlanılan rapora ulaşlamadığından ölüm hadisesine dair başlatılan tahkikatın nasıl neticelendiği hakkında herhangi bir şey söyleme imkânından yoksun kalınmıştur. ${ }^{53} 1909$ senesinde yaşanan benzer bir hadisede de Karcikanlı Yusuf adlı birisinin Govast'dan Oseb ve Mursik ismindeki şahıslarca zehirlendiği iddia olunmuştu. Söz konusu şahıslar gözaltına alınmışken ölünün midesi de gerekli tahlillerin yapılması için Tıbbîye Mektebi'ne gönderilmişti. ${ }^{54}$ 
Zehirlenme şüphesiyle girişilen en ilgi çekici otopsilerden birisi de 1905 senesinin Temmuz ayında, Meliha isimli bir kadının cesedi üzerinde gerçekleştirilmiştir. Ölümünden $\operatorname{tam} 6,5$ ay sonra babası tarafindan ortaya atllan iddiaya göre Vefa'da, Cemal Hanım'ın hanesinde kirayla ikamet eden Meliha Hanım hamileyken çocuğunu düşürmesi için kocası tarafindan kendisine verilen karabaş ${ }^{55}$ adında bir otun kullanımını müteakip ölmüştü. Kendilerine intikal eden bu iddiadan sonra İstanbul Bidayet Mahkemesi Savcllı̆g'nda görevli Simon, Dimitraki ve Feyzi Beyler ölüm sebebinin aydınlığa kavuşturulması adına ceset üzerinde otopsi ameliyatı icrasına karar vereceklerdir. Bu doğrultuda babasının kılavuzluğunda ve hep birlikte Meliha Hanım'ın defnedilmiş olduğu mahalle gidilmiştir. Kabrinden çıkarılan ceset tabutuyla uygun bir mahalle taşındıktan sonra kefeni açılmıştır. Vücudun bazı mahallerinin mumya ${ }^{56}$ halinde bulunuyor olmasına rağmen büyük bir kısmının çürümüş olması sebebiyle bu durumdan pek bir şey istifade olunamayacağı ifade edilmiştir. Bu şartlar altında icra olunan otopsi ameliyatının ilk safhasına dair tutulan kaytlar arasında ise şu bilgiler vardır:

Yumuşak dokular dövülmüş, diğer azalar da birbirinden ayrılmıştır. ${ }^{57}$ Gerek gögüs kafesi (kavsara-i sadrî) içindeki organlar gerekse diğer iç organlar tamamıyla çürümüştür. Göğüs kafesi ve karın (batn) içinde, külçe ve sıvı halde bulunan gögüs kemiği (azm-i kas) ve bağırsak (meâ') parçaları bir kavanoz içerisine yerleştirilmiştir. Ayrıca pamuklarla silinen kemiklerden (izâm) çıkan maddeler de ayn bir kavanoza konulmuştur. Mühürlenen bu kavanozlar da karabaş maddesinin araşturılmasına yönelik tahliller için Mekteb-i Tibbîye-i Şâhâne Nezâreti'ne, mezarın dört bir tarafindan alınan numune topraklarla ${ }^{58}$ birlikte gönderilmiştir. ${ }^{59}$

55 Osmanlılar döneminde koleranın tedavisinde bile yer almış olan karabaş lavantası eskiden antiseptik, yara iyileştirici, yatı̧̧ırıcı, balgam söktürücü, idrar yollan enfeksiyonların giderici, egzama yaralanun iyileştirici, sinirleri ve kalbi güçlendirici etkileri sayesinde sıkça kullanılırken, bugün daha seyrek kullanılır olmuştur. Karabaş otunu hamile kadınlann kullanmasımın sakıncalı olduğuna dikkat çekilmektedir. (http://weze.ebithicom adresinden 25.07.2010 tarihinde alınmıştur).

so Sicak, kuru, cereyanh havada ve açikta bulunan cesetler suyunu kaybederek kururlar, tupta bu hale mumyalaşma ismi verilir. Mumyalaşma cesedin tamamında meydana gelebileceği gibi burun, el, ayak gibi kısımlarda da görülebilir. Mumyalaşmanın adli tp bakımından önemi pek fazladır. Cesette mevcut etken eylem belirtileri, yara, bere vs. uzun seneler hiç bozulmadan muhafaza olunurlar. Mumyalaşmanın gelişmesi için gerekli süre birkaç haftadan birkaç yıla kadar değişebilir. Dokular bir kere mumyalaştıktan sonra çok uzun yıllar değişmeden kalabilmektedir. Nitekim, Mısırlılann binlerce sene önce yaptıklan mumyalar bugüne kadar hị̧ şeklini bozmadan saklanabilmiştir. Bkz. Oğuz Polat, Adli Tip, İstanbul 2000, s.28; Polat-Inanci-Aksoy, a.g.e., s. 18.

57 Mumyalaşan cesetlerde eklem ilişkileri korunmuş bir vaziyette kalır. Yumuşak dokular yoğunluk kaybeder, ancak ortadan kaybolmazlar. Bkz. Hanc1, a.g.e., s. 303.

58 Otopsi için mezann dört bir tarafindan toprak alınmasının sebebi cesette zehir olmadiğ halde gömülü olduğu toprakta zehirli maddelerin bulunabilir olmasındandır. Bkz. Gök, a.g.e., s. 40.

59 BOA, ZB, 303/159; 7 Kânunusani 1321/20 Ocak 1906. 
Erzurum'da yaşanan zehirlenme iddiah bir başka ölüm vakası Osmanlı otopsi tarihine ilişkin önemli ayrıntıları bünyesinde barındırmaktadır. Bunlardan birisi otopsi girişiminin -en azından bu çalışma için- 1846 gibi oldukça erken bir tarihe tesadüf etmesidir. Diğer ilginç nokta ise o tarihlerde Osmanlı ülkesinde ölen yabanclara otopsi uygulamanın isteğe bağhı olduğudur. Arabistan Ordu Müşiri Ali Namık tarafindan aktarılan söz konusu hadise genel hatlarıyla şu şekilde gelişmiştir: Erzurum İran maslahatgüzar vekili olan Ağa Hüseyin adındaki şahıs Erzurum müşiriyle gerçekleşen bir görüşmenin ardından konaklamakta olduğu Derviş Ağa Hamı'na giderken yolda bir ağrıya yakalanıyor, odasına vardığında ise safra ile karışık kan kustuktan on dakika kadar sonra ölüyordu. Hadise bölgedeki İran murahhasinca idarî makamlara bildirildiğinde hemen birkaç tabip tayin olunuyor ve ceset üzerinde gerçekleştirilen bazı incelemelerden sonra Ağa Hüseyin'in zehirlenmiş olabileceğine dair bazı alametler görüldüğü ifade ediliyordu. Bunun üzerine ölüm sebebinin kesin olarak ortaya çıkarılması için Erzurum karantina hekimi Dekimyon tarafindan ceset üzerinde otopsi yapılması teklif olunmuştu. Ancak orada bulunan İranlı tacirlerin otopsiye ruza göstermemesinden sonra Ağa Hüseyin'in cesedi kenar şehirdeki kabristana defnedilmişti. Otopsi icra olunamayınca da tüccar arasında ölümle ilgili söylentilerin ardı arkası kesilmemişti. Kimilerine göre Ağa Hüseyin birkaç gün evvel yüreğine giren yelden, kimilerine göreyse bir gün önce İranlı Ağa Hekim adında birisinin kendisine ikram ettiği şerbetten zehirlenerek ölmüştü. ${ }^{60}$ Dolayısıly bu hadise yukarıda sunduğu önemli ayrıntıların yanında neticesiyle de otopsinin önemine işaret etmektedir.

\section{3) Salgin Hastahklar ve Otopsi}

Tarihi boyunca birçok bulaşıcı hastalıkla savaş vermiş olan imparatorluk idaresi ile söz konusu savaşta aynı saflarda yer alıp, haylice bir kayba uğrayan imparatorluk halkında bulaşıcı hastalıklara karşı nasıl bir tepkimenin husule gelmiş olduğunu burada uzun uzadiya izaha gerek yoktur. Mesela otopsi raporu yukanda incelenen Sami Kaptan'ın koleradan öldüğüne dair iddialanı ortaya çıkması bile Hanya ahalisi arasında büyük bir panik havası yaratmaya yetmişti. ${ }^{61} \mathrm{Bu}$ panik ve korku havasındandır ki otopsiye sıcak bakmayan Osmanlı insanları ölüm şüphesi kolera, tifo gibi bulaşıcı hastalıklar olunca ameliyatların icra sahasına aktarılmasında herkesten daha istekli olmuştur. Hatta bazen söz konusu isteklilik ölülerin kabirlerinden çıkarılmasına kadar uzanmıştur. Mesela, saray mutfağında misafir olarak kalan aşçı

${ }^{60}$ BOA, A.MKT, 35/87; 18 Safer 1262/15 Şubat 1846.

${ }^{61}$ BOA, DH.MKT, 1342/5; 7 Muharrem 1301/8 Kasım 1883. 
çırağı Bolulu Yunus'un cesedi, ölümünün ardından ortaya çıkan bazı şüpheler üzerine defnedildiği Maçka kabristanından çıkarılmak suretiyle üzerinde otopsi ameliyatı icra olunmuştu. Ancak vücudunda zerre kadar da olsa şüphe uyandıracak herhangi bir alamet görülmediği otopsi raporuna not edilmişti. ${ }^{62}$

Merkezî idarenin bulaşıcı hastalıklara karşı büyük bir korku taşımanın yanında daha başka endişeleri de vardı. Koleradan ölen Sivash Agop'un otopsi ameliyatının icrası sırasında söz konusu endişeleri görebilmek mümkündür: Nitekim ameliyatla ilgili süren tartışmalar arasında kolera gibi mevsim hastalıkları üzerine fennî tetkikler icra edilirken son derece dikkatli ve titiz davranılması gerektiği merkezî idare tarafindan sık sık vurgulanmıştır. Çünkü Osmanlı ülkesinde böylesi hastalıkların varlığına ilişkin duyulacak en ufak bir haber dahi İstanbul'un dışanda "bulaşık" olarak tanıtılmasına sebep oluyor, bu tanıtım ise Osmanlı başkentine gelecekleri yollarından alıkoyduğu gibi, kaldırılmasına çalışılan karantinaların süresini uzatıyordu. Böyle bir gelişme ise devleti madden ve manen zarara uğratmaktaydı. Bunun içindir ki öyle şüpheli hastalann hemen resmî bir müşavere heyeti ile sthhiye dairesinden bir iki tabibin de hazır bulunduğu sırada, bakteriyoloji fennine uygun olarak ve hiç vakit kaybedilmeksizin tedavilerinin yapılması, ölüm halinde ise oldukça titiz bir surette otopsi ameliyatlarının icra olunması gerekmektedir. Hastalar veya ölülerle ilgili sağhklı bir karara varabilmek ancak bu takdirde mümkün olabilmektedir. ${ }^{63}$ Ustelik daha 1853 senesinde yaşanan bir hadise sırasında devlet bu husustaki tutumunu açıkça ortaya koymuştu. Şöyle ki; Ohannes adındaki bir katoliğin bulaşıcı hastalıktan öldüğüne dair karantina idaresinin bildirimi üzerine cesedin Başpapaz nezaretinde defnedildiği Hariciye Nezareti'ne haber verilince hemen Katolik Patriği'ne hitaben bir tezkere kaleme alınmıştı. Tezkerede; bulaşıcı hastalıktan ölmüş olduklan iddia edilen şahısların keşif ve muayeneleri yapılmadan ve zabıtaya haber verilmeksizin defnedilmelerinin kanunlara aykırı ${ }^{64}$ bir hareket olduğuna dikkat çekilmiş ve huzura çağırılacak olan Başpapaza da benzer bir hadisenin yaşanması halinde cezalandırılacağının sert bir dille tembih olunması gerektiği ilgililere bildirilmiştir. ${ }^{65}$

Yine ağırlık bulaşıcı hastalıklarda olmak üzere ölüm sebeplerine dair duyulan şüpheler bazı ordu mensuplarının cesetleri üzerinde de otopsi ameliyatı icra olun-

1.2 BOA, Y.PRK ZB, 10/102; 12 Cemaziyelâhir 1310/1 Ocak 1893.

1.3 BOA, Y.Mt , 95/+3; 4 Zilhicce 1311/8 Haziran 1894.

1. 24 Nisan 1930 tarih ve 1953 Sayılı Umumi Hıfzıssihha Kanunu'nun 215.maddesine göre de defin ruhsatı alınmadıkça ve ibraz olunmadıkça hiçbir ceset gömulemez. Bkz. Polat-Inanıcı-Aksoy, a.g.e., s. 25 .

is BOA, HR.MKT, 61/88; 29 Şevval 1269/5 Ağustos 1853. 
ması lüzumunu ortaya çıkarmıştr. Mesela, Tırnovacık Hudut Bölüğü'nden Dereköy Kumandanlığ'na çekilen bir telgrafta bölükte ölen askerlerin otopsi ameliyatları icra olunduktan sonra o mahalde defnedildiklerinden bahsediliyordu. ${ }^{66}$ Aynı şekilde Manastr Jandarma efradından olan Halil bin Hüseyin adlı asker de duyulan lüzum üzere gerçekleştirilen otopsi ameliyatından sonra defnedilmişti. ${ }^{67}$

İşte Osmanllardan bugüne, yaşanan bulaşıcı hastalıklar münasebetiyle kazanılan derin ve acı tecrübeler sayesindedir ki Türkiye'de bulaşıcı bir hastalıktan öldüğünden şüphe duyulan şahıslar üzerinde yakınlarının rızası alınmaksızın dahi otopsi icra olunabilmiş ve bu hal 24 Nisan 1930 tarih ve 1953 Saylı Umumî Hıfzıssıhha Kanunu'nun 70.maddesiyle de hüküm altına alınmıştır. ${ }^{68}$ Buna göre; vakanın adlî bir sorun taşımasının yanında diğer bütün durumlarda otopsi için hasta sahiplerinin yazılı izinlerinin alınması gerekmektedir. ${ }^{69}$ Ancak yakın bir tarihte yapılan düzenlemelerle, ölüm sebebi kesin olarak anlaşılıncaya kadar cesetlerin adliyeye ait olduğu hüküm altına alınmıştır. CMUK'un 79 ila 83. maddeleri böyle durumlarda nasıl bir yol izlenileceğine dair hükümleri taşımaktadır. ${ }^{70}$

\section{4) Cinayet ve Otopsi}

Osmanllar döneminde otopsi ameliyatlarına konu olan ölüm vakalarına ait iddialar arasında cinayetler de yer almaktadır. Cinayet iddiasıly cesedi üzerinde otopsi ameliyatı icra edilmesi isteminde bulunulan şahıslar arasında Osmanh Imparatorluğu'nda meşrutî idarenin tesisinde başlıca rolü oynamış şahsiyetlerden birisi olan Mithat Paşa da bulunmaktadır. Saray ile Hicaz valisi arasında Mithat Paşa'nın ölümünden (1884) hemen sonra gerçekleşen bir dizi yazışmadan böyle bir girişimde bulunulduğu anlaşılmaktadır. Girişimin gayesi; Mithat ve Damat Mahmud paşaların hastalıktan değil de daha başka sebeplerden ölmüş olabileceklerine dair gerek yerli ve yabancı basinda yer alan haberlerin, gerekse bazı ileri gelen devlet temsilcileri ile halk arasında yayılmakta olan dedikoduların önüne geçebilmektir. Bu doğrultuda göstermelik olma ihtimali yüksek olan bir dizi yazışmadan sonra Hicaz Valisi otopsi ameliyatlanı icra etmek üzere 20 Mays 1884 tarihinde Taife gitmiştir. 26 Mayıs'ta vali tarafindan Yıldız'a takdim olunan bir tahriratta ise paşaların ölüm sebeplerine ilişkin ayrınth rapor ve mazbatalarla bazı jurnallerin Saray'a havale olunduğundan bahsedilecektir. Ancak Saray'dan mevzûbahis vesikaların kendilerine

\footnotetext{
${ }^{66}$ BOA, DH.EUM.6.Şb, 51/29; 24 Ramazan 1333/5 Ağustos 1915.

${ }^{67}$ BOA, TFR.I.MN, 15/1421; 25 Cemaziyelevvel 1321/19 Ağustos 1903.

${ }^{68}$ Gök, a.g.e., s. 49; Oztürel, a.g.e., s. 224.

${ }^{69}$ Talia Bah Aykan, Otopsi Tekniği ve Yardema Bilgiler (I.Kitap), İstanbul 1986, s. 13.

${ }^{70}$ Sankardaşoğlu, a.g.e., s. 38.
} 
ulaşmadığına dair yapılan açıklamaya rağmen vali 13 Haziran tarihli cevabî yazısında bunlan göndermiş olduğunu yineleyecek, daha sonraki yazışmalarda ise ölüm raporlarına ilişkin herhangi bir göndermede bulunulmayacaktır. ${ }^{71}$ Sarayın buradaki ısrarcı tutumunun paşaların ölüm sebeplerine ilişkin olarak kendisine atfedilen cinayet şüphelerini dağıtma gayesinden mülhem olabileceği akla gelmektedir. Söz konusu ölümlere dair çelişkilerin hala tam olarak bertaraf edilememiş olması elbette herhangi bir baskıya maruz kalınmaksızın ve tamamıla fennî usullere uygun olarak girişilen bir otopsi ameliyatı ile yine aynı usul üzere hazırlanmış olan bir raporun mevcut olmayışından kaynaklanmaktadır.

Yukarıdaki örnek hadise otopsi ameliyatlarmın önemine fazlasıyla vurgu yapmaktadır. Paşalar kadar meşhur olmasa da Hadimli Mustafa'nın 1919 senesinde, Konya'da, Zindankale civarında ve toprakla örtülü bir vaziyette bulunan cesedi üzerinde icra kılınan otopsi de, bu ameliyatların; ölüm sebeplerinin aydınlatılmasındaki önemini ortaya koymaktadır. Yoksa otopsisi icra olunmadan Mustafa'nın boğazından bir iple boğularak öldürüldüğü nasıl anlaşılacaktı? Cinayetin ortaya çıkmasından sonra olayla ilgisi olduğu iddia edilen ve gözaltına alınan iki şahıs -belki de- suçlu oldukları halde ellerini kolların sallayarak ulu orta dolaşacaklardı. ${ }^{72}$ İskilavlı Gorgi, Siroz Mebusu Dalçof Efendi'ye sunduğu arzuhalinde tam da böylesi bir eksiklikten yakınıyordu. Çünkü Gorgi'nin kardeşi kasıtlı olarak öldürülmüşken, cesedi keşfe gelen memurlara nüfuz sahibi olan katiller tarafindan kendi kendisini vurduğu şeklinde bir şerh düştürülmüştü. Şimdi ise Gorgi etrafta gezinmekte olan katillerin yakalanmasımı, ayrıca tayin olunacak uzman tabipler vasıtasıyla kardeşinin cesedi üzerinde otopsi ameliyatı icra kılınmasım istiyordu. ${ }^{73}$

Cinayet iddiasıyla girişilen son örnek otopsi ameliyatı ise 1906 tarihlidir. Otopsisi yapılansa Tuzla'da ikamet etmekte olan İran tebaasından Kasap Ali Rıza'nın üvey oğlu Mehmed Cemaleddin'dir. Ancak Etibba Dairesi tarafindan hazırlanan otopsi raporunda vücudunda cinayete dair herhangi bir alamete tesadüf olunamadığı ve kendisinin beyin kanamasından (ihtikan-ı dimağigye) öldüğu kaydedilmiştir. ${ }^{74}$

\footnotetext{
${ }^{71}$ BOA, T.EE.d, 1090.

72 BOA, DH.ELM.AYS, J/94; 20 Recep 1337/21 Nisan 1919.

7 BOA, DH.MUI, 108-1/17; 19 Cemaziyelâhir 1328/28 Haziran 1910

BOA, ZB, $668 / 55: 11$ Mayıs 1322/24 Mays 1906.
} 


\section{5) Yanlş̧ Tedavi/İlaç ve Otopsi}

Osmanlılar zamanında otopsiye konu olan ölümlerden bazılarının da tabiplerin yanlş̧ tedavisinden veya tavsiye ettikleri ilaçların yan etkisinden kaynaklandığına dair iddialar ortaya atılmıştır. Mesela, 1906 senesinde Tabip Aleksandros Efendi tarafindan uygulanan yanlış ve kötü tedaviden dolayı bir kadının öldüğü iddiasıyla Zaptiye Nezareti'ne başvuruda bulunulmuştu. Bunun ne derece doğru olduğunu saptamak için de kadının cesedi üzerinde otopsi icrası lüzumu ortaya çıkmıştır. Bu doğrultuda nezaret bünyesindeki tabiplerce uygulanan otopsi ameliyatından başka, tahlilleri yapılmak üzere kadının çıkarılan iç organları da Umum-i Mekâtib-i Askeriye-i Şahane Nezâreti'ne gönderilmiştir. ${ }^{75}$

Yanlı̧ ilaç kullanımı neticesinde gerçekleştiği iddia edilen ölüm vakalarından biri ise 1902 senesinde, İstanbul'da yaşanmıştr. İddiaya göre Başıüyük Köyü'nde sakin olan Halil Çavuş adlı şahıs Kartal Belediye tabibi tarafindan kendisine verilen ilacın kullanımını müteakip ölmüştü. Cesedin keşfine gönderilen memurun hazırlayarak Úsküdar Mutasarnfllğ'na takdim ettiği raporda ölümün gerçek sebebinin anlaşılması için vakit kaybedilmeksizin otopsi ameliyatının icra olunması lüzumuna dikkat çekiliyordu. Bu raporla birlikte söz konusu ilaçlar da tahlilleri yapılmak üzere mutasarnfllk kanalıyla Zaptiye'ye, oradan da Tibbîye Mektebi'ne havale olunmuştu. ${ }^{76}$ Ancak tabiplerin yanlş̧ tedavi ve tavsiyelerinden kaynaklandiğ iddia edilen bu ölümler neticesinde girişilen otopsi ameliyatlarna ilişkin raporlara ulaşmak mümkün olmadığından iddiaların doğruluk dereceleriyle ilgili herhangi bir yorumda bulunma imkânı da hâsıl olmamıştır.

Son olarak, incelenen vesikalar arasında bir de boğulma neticesinde girişilmiş olan otopsi ameliyatı vardır. 1919 tarihli bu ameliyat Kalyos Köyü'nden Yorgioğlu Tanaş ismindeki ve 16 yaşındaki bir çocuğun Çekmece Gölü civarında, Niko Çeşmesi'nde ölmesi neticesinde gerçekleşmişti. Çekmece hükümet tabipleri ve Belediye tabibi tarafindan icra kılınan otopsi ameliyatı neticesinde çocuğun boğularak ölmüş olduğu teyit edilmişti. ${ }^{77}$ Belki sudan çıkarılan bir ceset için boğulmaktan başka bir ölüm sebebi aramak yadırganıp, otopsi ameliyatına girişilmesi de gereksiz olarak değerlendirilebilir. Ancak boğulanlar üzerinde uygulanan otopsi; kişinin ölümünün suda boğulmaya bağh mekanik asfiksi sonucu meydana gelip gelmediği, kişinin ölmeden evvel alkol, uyutucu veya uyuşturucu alı almadığı, ölümüne tesir eden bir

\footnotetext{
${ }^{75}$ BOA, ZB, 345/108; 27 Haziran 1322/10 Temmuz 1906.

${ }^{76}$ BOA, DH.MKT, 501/53; 3 Safer 1320/12 Mays 1902.

7 BOA, DH.EUM.AYŞ, 5/101; 21 Receb 1337/22 Nisan 1919.
} 
darp-cebir işaretine rastlanıp rastlanmadığı veya soğuk suyun aniden sinirlere bir inhibisyon yapıp yapmadığı gibi sorulara cevaplar üretebilmek, ${ }^{78}$ dolayısıla ölüm sebebini net bir şekilde açığa çıkarmak adına büyük bir öneme sahiptir.

\section{E- Otopsi Ameliyatlarına İlişkin Malî Sorunlar}

Osmanlılar zamanında en az otopsi ameliyatlarının uygulanması kadar üzerinde tartışılan meselelerden birisi de gerek ameliyatlan gerçekleştiren tabiplere ödenecek ücretlerin, gerekse ameliyatlarda kullanılan malzeme bedellerinin hangi kanallardan karşlanıp, tabiplere ne şekilde tahsis edileceği olmuştur. Mesela, Ankara Vilayeti'nden Umum-u Mekâtib-i Askeriye-i Şahane Nezareti'ne çekilen telgrafla; belediye tabiplerinin otopsi ameliyatlarında kullanacaklan sandık, çanta, özel şırınga, kavanoz vs. malzemelerin hangi türden olmaları gerektiğinin, yerel idarî birimlerce nereden ve kaçar kuruşa temin edileceklerinin belirsizliğinden dem vurularak, kendilerinin bu hususta aydınlatılması istenilmişti. ${ }^{79}$

Ucretlere dair hükümlerin belirsizliği ve süreklilik göstermemesi bu husustaki karışıklı̆̆ daima gün yüzüne çıkarmıştır. Denizli Sancağı Belediye Tabibi Şakir Efendi tarafindan 1898 senesinde Adliye Nezareti'ne takdim kılınan arzuhalde, bazen mezarlıklardan çıkartılan çürümüş ve kokmuş cesetleri de kapsayan otopsi ameliyatlarının uygulanması meselesinin söz konusu açıklıktan uzak oluşu dile getirilecektir. Şakir Efendi, otopsi uygulamasında koku giderici olarak kullanılan ilaçlara ait ücretlerin kendilerine ödenmesi sırasında bir ikilem yaşanmakta olduğundan bahsederken, üç beş gün gibi kısa bir süre önce defnedilmiş olan cesetler üzerinde gerçekleştirilecek otopsi sırasında da bu ilaçların kullanımının söz konusu ücret kapsamına dâhil edilip edilmeyeceği hususunda kendisinin aydınlatılmasını talep etmektedir. Bunun üzerine Adliye Nezareti'nden Denizli'deki ilgililere; ölünün sadece bir uzvunun incelenmesinin dahi otopsi demek olacağına dair bütün vilayetlere tebliğ kılınmış olan bir kararnamenin mevcudiyeti hatırlatılırken, Şakir Efendi'nin mağduriyetinin de giderilmesi bildirilmiştir. ${ }^{80}$ Anlaşılan o ki benzer hadiselerin yaşanmasından dolayı söz konusu kararname 1902 senesi içerisinde bütün vilayetlere ve mutasarrıflıklara hitaben bir kez daha gönderilmiştir. Buna göre alenen işlenen suçların incelenmesi için gönderilen tabip ve memurlardan başka kamu hukuku adına celp olunan şahitlere verilecek ücret ve harcırahlarla beraber otopsi ameliyatlarına ilişkin diğer harcamaların hemen ödenmesi gereken adlî masraflardan olma-

\footnotetext{
${ }^{7}$ Sankardaşoğlu, a.g.e., s.62; Balcı, a.g.e., s. 105.

"BOA, DH.MKT, 2461/86; 23 Zilkade 1318/14 Mart 1901.

sa BOA, DH.MKT, 2110/105; 10 Cemaziyelevvel 1316/26 Eylü 1898.
} 
sına binaen ödeme hususunda herhangi bir ertelemeye mahal vermenin uygunsuzluğuna dikkat çekilerek, bunların hemen ödenmeleri gerektiği ilgililere hatırlatılmıştur. $^{81}$

Cinayet iddiasıyla girişilen otopsi ameliyatlanında kullanılan ilaçlarla, ameliyatları gerçekleştirmek üzere olay mahalline giden tabiplere ödenecek ücretlerin de daha sonra mahkeme kararı ile haksızlığı sabit olacak taraftan tahsil edilmek üzere mal sandıklarından karşlanması hükme bağlanmıştır. Ancak içinde bulunulan ekonomik güçlükler sebebiyle ücretlerin halk kesiminden tahsili o kadar da kolay olmamıştır. Mesela, kocası Palaz Ali tarafindan maruz kaldığı darbın tesiriyle öldüğü iddia edilen Habibe Hatun'un otopsi ameliyatını icra eden tabipler mevzubahis zorlukla karşılaşmışlardı. Çünkü fakirliklerinden dolayı davalı ve davacı olan taraflardan ücret tahsiline gidilemeyince bahsolunan usul üzere mal sandiğına başvurulmuştu. Ancak gereksiz akçe sarfina sebebiyet vereceği bahanesiyle sandık herhangi bir ödeme yapmaktan kaçınmıştı. Bunun üzerine Beykoz Kazası Kaymakamlığ'ndan Maliye Nezareti'ne sunulan tahriratta; ülkede süregiden bu çaresizliğin "âdil ve hakkan vâsta-i te'mîni olan ameliyyât-ı mukteziyyenin" icrasını hem geciktirmekte hem de engellemekte olduğundan bahsedilerek, bunun kesin bir surette halledilmesi kendilerinden talep olunmuştur. ${ }^{82}$

Fakat otopsi ücretlerini alamayan tabiplere yardımcı olunmasını isteyen vesikaların çokluğundan ve sıklı̆ından anlaşlan o ki ücretlerin tahsis edilmesi problemi imparatorluğun çöküşüne kadar süregitmiştir. Bu nedenle de devlet merkezi ile çeşitli vilayetler arasında ücret sorununa ve bu sorunun aşılması aşamasında neler yapılabileceğine dair yoğun bir yazışma trafiği yaşanmıştur. Mesela Edirne Vilayeti'nden Umum-u Mekâtib-i Askeriye-i Şahane Nezâreti'ne takdim olunan bir tahriratta Tibbîye Cemiyetince kararlaşturılan otopsi ücretlerinin tabiplere sırf kamu hukukunu muhafaza adına eksiksiz ve peşin surette ödenmesinin gerekliliğinden, aksi takdirde onları vazifelerini ifaya zorlamanın uygunsuzluğundan bahsedilmişti. ${ }^{83}$

Bazen de tabiplere hak ettikleri otopsi ücretlerinin ödenmesi aşamasında imparatorluğun en üst makamlan dahi devreye sokulmuştur. Mesela, Fırta Nahiyesi tabibi, Alibey köyüne giderek gerçekleştirdiği otopsi neticesinde alması gereken ücretin ödenmesi aşamasında kendisine yardımcı olunmasını istediği Karesi Mahkemesi'nin umursamaz tavrıyla karşılaşınca mağduriyetini ifade eden arzuhalini yis 1902.

${ }^{81}$ BOA, BEO, 1853/138937; 16 Safer 1320/25 Mayss 1902; 1853/138904; 16 Safer $1320 / 25$ Ma-

${ }^{82}$ BOA, DH.MKT, 2519/7; 20 Rebiyülâhir 1319/ 6 Ağustos 1901.

${ }^{83}$ BOA, DH.MKT, 569/37; 28 Cemaziyelevvel 1320/2 Eylül 1902. 
evvela Meclis-i Tıbbîye-i Mülkiye ve Sıhhiye-i Umumiye Reisliği'ne takdim etmiştir. Ardından arzuhali bu kanalla Dâhiliye'ye, oradan da Adliye Nezareti'ne havale olunacaktır. Nihayet tabip efendinin mağduriyetinin ortadan kaldırılmasına dair Adliye Nazırı imzalı emir Karesi Ceza Mahkemesi Riyaseti'ne gönderilecektir. ${ }^{84}$ Aynı şekilde Hüdavendigâr Vilayetine bağlı Bolvadin'in Yakacık Nahiyesi'nde şüpheli bir şekilde öldüğü iddia edilen bir kadının cesedi üzerinde otopsi ameliyat icra eden Aziziye Kazası Belediye Tabibi Hıfı Nuri Efendi kadının kocasının fakir olmasından dolayı otopsi ücretinin tahsisi hususunda mağdur edilecektir. Bunun üzerine kendisine yardımcı olunması noktasında başvuruda bulunduğu yerel idarî birimlerin aldırmaz tavırlarıyla karşılaşınca -bir önceki misalde olduğu gibi- son çare olarak Meclis-i Tıbbîye-i Mülkiye ve Sıhhiye-i Umumiye Reisliği'ne halini arz edecektir. Belediye tabiplerinin bu şekilde kanuna muhalif muamelelere maruz kalmalarının uygunsuzluğuna dikkat çekilmek suretiyle mesele Dâhiliye Nezâreti'ne intikal ettirilecek, oradan da Hüdavendigâr Vilayeti'ne çekilen telgrafla Hıfzı Nuri Efendi örneğinden hareketle tabiplerin otopsi ameliyatlarını gerçekleştirmek için sarf ettikleri masrafları, geçimlerini ucu ucuna sağlamakta olduklanı maaşlanından karşılamak mecburiyetinde bırakıldıklanından, bunun da kendilerini haylice geçim sıkıntısına düşürmekte olduğundan, dolayısıyla otopsi ücretlerinin derhal kendilerine ödenmesi gerektiğinden bahsedilecektir. ${ }^{85}$ Oysa ki Adliye Nezâreti; cinayet, zehirlenme ve boğulma gibi sebeplerden kaynaklanan ölüm vakalarını incelemek için olay mahalline sevk olunan tabip, memur ve şahitlere verilecek ücret ve harcirahların yanı sıra otopsi masraflarının da ertelenmeden karşılanması gerektiğini her firsatta bütün vilayetlere tebliğ etmekten geri durmamıştır. ${ }^{86}$

Daha sonraki yllarda ise tabiplere otopsi ücretlerinin tahsisi aşamasında hazineyi zarara uğrattığı gerekçesiyle mal sandıklarından istifade olunması seçeneğinin devre dışı bırakılmış olduğu anlaşılmaktadır. Çünkü davacıların ödeme güçlerinin olup olmadığına bakılmadan otopsi masraflarının mal sandıklarından temini, ayrıca haksız çıan tarafların uzun süre otopsi ücretlerini ödememeleri mal sandıklarının az zaman zarfinda boşalması gibi bir neticeyi doğurmuştur. Bundan dolayıdır ki 16 Ekim 1902 tarihinde bütün vilayetlere gönderilen emirle mal sandıklarına ödenmemiş olan ücretlerin süratle tahsil olunması idarecilere bildirilmişti. ${ }^{87}$

${ }^{34}$ BOA, DH.MUI, 21-2; 26 Ramazan 1327/11 Ekim 1909.

ss BOA, DH.MUI, 58/50; 17 Muharrem 1328/29 Ocak 1910.

${ }^{36}$ BOA, BEO, 1935/145123; 14 Recep 1320/17 Ekim 1902.

${ }^{87}$ BOA, DH.MKT, 606/25; 1 Şaban 1320/3 Kasım 1902. 
Merkezî idarenin yetersiz ve belirsiz tedbirleri karşısında tabiplerin bazen kendilerince çözüm yolları üretmeye çalıştıkları da görülmektedir. Hazırladıkları otopsi raporlarım mahkemeye teslim etmeme tabiplerin başvurduğu tedbirlerden birisi olmuştur. Mesela, Haymana kazasında 2 aylık bir bebeğin maruz kaldığı darbın tesiriyle öldüğu iddiası üzerine girişilen otopsi ameliyatını icra eden belediye tabibi otopsi ücreti olan 300 kuruşu almadan otopsi raporunu ilgililere vermeyeceğini ifade etmişti. ${ }^{88}$ Bundan daha kötüsü ise ücretlerin ödenemediği durumlarda otopsi ameliyatlanını icra sahasına aktarılmaması gibi bir engelle karşılaşmak olmuştur. Nitekim, Ergiri Sancağı'nın Nepravişte köyünden olan Hasibe Hanım arzuhalinde kocası Ömeroğlu Vehbi'nin köylüleri Nafiz Ulvi tarafindan yaralanmasindan bir ay sonra öldügünü ifade ettikten sonra tabibe ödenmesi gereken ücreti ödeyemediğinden otopsi ameliyatının, dolayısıyla hukukun uygulamaya konulamadığından yakınıyordu. ${ }^{89}$ Aynı şekilde otopsi kapsamında girişilen tahlil harçlarının ödenmemesinin kaidelere aykırı olduğuna, tahlil için gönderilecek her bir parça için 5 mecidiye ödenmesi gerektiğine ve bundan sonra harçların ödenmemesi durumunda tahlillerin yapılmayacağına dair Mekteb-i Tıbbiye-i Şâhâne'nin talebi üzerine 25 Aralık 1893 tarihinde Dahiliye Nezâreti'nden bütün vilayetlere hitaben bir bildirimde bulunulmuştu. ${ }^{90}$

Konu sorunlardan açılmışken son olarak şunu da belirtmekte fayda var ki; tabiplerin ücretlerini alamamaktan başka otopsi ameliyatlanyla ilgili olarak karşılaştıklan sorunlardan bir diğeri de vazife sahalarından oldukça uzak bölgelerde görevlendirilmeleridir. Sandıklı Kazasına bağlı Şeyhli Nahiyesi tabibi Yakup çalışığı nahiyeden saatlerce mesafe uzaklıkta bulunan bir köydeki vukuatın keşfine gönderilince Adliye Nezareti'ne sunduğu arzuhalinde söz konusu sorunu dile getirmekten çekinmeyecektir. Tabip Yakup'un üst makamlardan isteği mecbur kalınmadıkça otopsi ve diğer adlî hususların icrası için belediye tabipleri bulunan mahallere dışarıdan bir tabibin çağınılmamasıdır. ${ }^{91}$ Türkiye'de tabiplerin bu sıkıntılan 1953 tarihli Adlî Tıp Müessesesi Kanunu'nun 13.maddesi ile giderilmiştir. Buna göre adli tabipler, bulundukları yer ve vazifeler dışında herhangi bir mahal ve görevde istihdam olunamazlar. ${ }^{92}$

BuA, DH.MUI, $43-1 / / 1$; 12 Zilhicce 1327/25 Aralık 1909.

"1" BOA, DH.MKT, 1045/24; 3 Zilhicce 1323/29 Ocak 1906.

"91' Bingöl, a.g.m., s. 44.

${ }^{4}$ BOA, DH.MUI, 9-1/23; 27 Şaban 1327/13 Eylül 1909.

42 Oztürel, Adli Tip, s. 15,17; Adli Tip kurumunun yakın zamanlara kadar uygulanmakta olan otopsi tarifeleriyle ilgili olarak bkz. Adli Tip Kurumu Kanunu Döner Sermaye Tönetmeliği Ve Fiyat Listesi, (Adli Tip Kurumu Yaymlan), Istanbul 1983, s, 25. 


\section{F- Merkezî İdarenin Otopsi İçin Uygun Ortamı Sağlama Çabalan}

Osmanlılar zamanında gerçekleştirilecek otopsi ameliyatlarının daha rahat ve sağıklı bir ortamda sürdürülebilmesi adına çeşitli binaların inşası lüzumu ortaya çıłış ve bürokratlar arasında buna dair yoğun bir yazışma ve danışma trafiği yaşanmıştur. Yapımı düşünülen binaların başında otopsi ameliyathaneleri gelmektedir. Ameliyathanelerin yapılması lüzumu ilk olarak Umum-u Mekâtib-i Askeriye-i Şahane Nezâreti'nden Şûra-yı Devlet'e havale olunan bir tezkere ile gündeme getirilmiştir. Defnedildikten sonra ortaya atlan bir takım iddialardan dolayı kabirden çıkarılan cesetler üzerinde yapılacak otopsi ameliyatlarını öyle kabristanlarda, taş toprak içerisinde, birçok ahalinin gözleri önünde icra edilmesinin uygun olmayı̧ı ve özellikle de diğer ülkelerin birçoğunda bu tarz yapıların mevcudiyeti, ameliyathanelerin inşasını gerektiren haller olarak sıralanmıştır. İkişer odadan ve kargir malzemeden müteşekkil surette düşünülen ameliyathaneler İstanbul'da çeşitli mezheplere mensup kabristanlarda yapılacaktır. Bu kabristanlar ise şu şekilde sıralanmıştr: Üsküdar-Karacaahmed Kabristanı-Miskinler Tekkesi civan, KasımpaşaDoymazdere, Topkapı Kabristanı içerisinde, Baklalı-Rum ve Ermeni kabristanları ${ }^{93}$ ile Eyüp, Edirneyolu, Silivri Kapısı, Beykoz, Kadıköy, Rumelihisarı ve Beylerbeyi kabristanları.

Buraya kadar her şey yolunda gibi gözükmektedir. Lakin Osmanlı tarihini ilgilendiren hemen bütün meselelerde olduğu gibi konu binaların yapım finansmanımı sağlamaya gelince işler sarpa saracaktur. Şöyle ki ameliyathanelerden her birinin 8936,5 kuruşla vücuda getirilebileceği hesap olunduktan sonra Şûra-yı Devlet bütün masrafin Zaptiye Nezâretince karşılanmasına karar verecektir. Buna karşın Zaptiye Nazırı 24 Haziran 1903 tarihli cevabî yazısında otopsi ameliyatlarının savcıların talep ve iddialan üzerine icra edilmekte olduğu gerekçesiyle inşa masraflanını Adliye Nezâreti'nden karşlanması gerektiğine dikkat çekecektir. ${ }^{94}$ Adliye nezaretiyse otopsilerin savcllann gösterdiği lüzum üzerine icra edildiğini teyit etmekle birlikte ameliyatların uygulama sahasına aktarılmasında Zaptiye'ye bağlı sağlık memurlar1nın görev aldığın bahane ederek masrafların Zaptiye Nezâretince karşlanmasının gerekliliğinden bahsedecektir. ${ }^{95}$ Velhasl her iki taraf da ödemeye yanaşmak niyetinde olmadığını açıkça ortaya koymuştur. Üstelik Adliye Nazırı'nı ödeme yapmamak için elinde kendince haklı olan bazı kozları daha vardır. Mesela, savcılarca

${ }_{93}$ BOA, BEO, 1829/137151; 7 Muharrem 1320; 16 Nisan 1902; DH.MKT, 700/15; 2 Safer 1320/11 Mayis 1902.

${ }^{94}$ BOA, BEO, 2111/158285; 13 Rebiyülâhir 1321/9 Temmuz 1903.

${ }_{45}$ BOA, DH.MKT, 700/15; 2 Safer 1320/11 Mays 1902. 
kamu hukuku adına talep edilen otopsi ameliyatlan o kadar sık değil, senede sadece birkaç defa gerçekleş̧irilmektedir. Bu ameliyatlarda kullanılan ilaçlarla diğer ameliyat malzemeleri için ödenmesi gereken 3 liranın karşılığı olmadığından bu, daha sonra haksız çıkan taraftan tahsil olunmak üzere nezâret gelirlerinden karşılanmaktadır. Dolayısıyla ameliyathanelerin yapımı için gereken meblağın, bütçesinde inşaat kalemi olmayan ve diğer gelir kalemleri de alabildiğine yetersiz olan Adliye Nezâreti yerine, Şura-yı Devlet'in de mevcut kararına uygun olarak Zaptiye veya Dâhiliye nezâretleri tahsisatından karşılanmasının mecburiyeti ortadadır. Lakin daha sonra buna benzer yazışmalardan anlaşıldığı üzere hayli zaman geçtiği ve ameliyathanelere ait hesap pusulalan ile resimlerin de Sadaret'e takdim kılındığ halde bu hususta herhangi bir somut adım atılmamıştır. ${ }^{96}$

Otopsi ameliyatlarının daha rahat ve shhatli bir şekilde icra sahasına aktarılması için 1908 senesinde Umur-u Tibbiye-i Mülkiye ve Sthhiye-i Umumiye teşkilatı içerisinde bir de morg idaresinin kurulması, buna bağh olarak da bir morg binasının inşası lüzumu ortaya çımış ve ameliyathanelerin aksine herhangi bir paturtıya mahal vermeksizin bu binanın yapımına girişilmiştir. Buna göre inşa masrafları Umur-u Tibbîye-i Mülkiye ve Sihhiye-i Umumiye bütçesinden karşılanacaktır. Gerekliliği ve önemi aynca belirtilmiş olan bu morg müessesesi için müstakil bir binanın inşasına kadar Haydarpaşa'da bulunan Tıp Fakültesi'nden ameliyathane olarak istifade olunacaktur. Dolayısıyla bundan sonra gerek emniyete gerekse adliyeye ait olup otopsileri icap eden cesetlerin doğrudan Tip Fakültesi'nde morg müessesesi olarak ayrılan bölüme nakledilmelerinin gerekliliği Umur-u Tibbîye-i Mülkiye ve Sihhiye-i Umumiye Riyaseti'nin isteği üzerine Dâhiliye kanalıyla Adlìye Nezâreti ile Emniyet-i Umumiye Müdüriyeti'ne tebliğ olunacaktur. Lakin bu tebligatun hemen ardından Etibba Dairesi kendilerine bir soru yöneltecektir: Peki defnedilen cesetlerin bir iddia veya ihbar üzerine o ölümle ilgili ortaya çıkan şüpheleri dağıtmak amacyyla kabirlerinden çıkarılarak, üzerlerinde otopsi ameliyat icra etmek lazım gelse çürümeye ve kokuşmaya başlayanların uzak bir mahalden Tıp Fakültesi'ne sevk edilmeleri noktasında nasıl bir yol izlenecektir? Etibba dairesinin bu sorusuna verilen cevapsa; öyle cesetlerin yakın köylerle Eyüp ve Topkapı gibi memleketin oldukça uzak mahallerinden fakülteye sevk edilmeleri aşamasında sadece yaz mevsimlerinde biraz zorlukla karşılaşılacağı, bundan başka herhangi bir sıkıntının yaşanma-

${ }^{96}$ BOA, SS, 2731/26; 6 Recep 1321/28 Eylül 1903; BEO, 2197/164719; 25 Recep 1321/17 Ekim 1903; DH.MKT, 700/15; 2 Safer 1320/11 Mays 1902.

97 Onceleri müstakil bir morg binasının bulunmayışından dolayı Istanbul'da adlì otopsiler Askerî Tıbbiyye Teşrihhanesi'nde (Patolojik Anatomi Enstitüsü'nde) yapılmıştır. Bkz. Gök-Ozen, a.g.e., s. 1. 
yacağı yönündedir. ${ }^{98}$ Bugün cesetlerin memleket içinde taşınması sorunu Umumî Hifzıssihha Kanunu'nun 230.maddesine dayanılarak hazırlanan bir talimatname ile çözüme kavuşturulmuştur. Buna göre; ceset, $\% 5$ asit fenikli suya baturılarak ıslatılan çarşafa sarılıp, lehimli teneke tabuta konulmak suretiyle taşınmalıdır. ${ }^{99}$

\section{G- Osmanh Tip Talebeleri ve Otopsi}

Çalışmanın başında da dikkat çekildiği üzere, Doktor Bernard'ın girişimleriyle 1841 yllında yayımlatılan bir ferman sayesinde Avrupa'daki tup okullannda olduğu gibi Türkiye'de de kadavralar üzerinde disseksiyon tatbikatı yapılmaya başlanmıştur. ${ }^{100}$ Adlî tup dersleri de Mekteb-i Tıbbıye-i Şâhâne'nin ders programında "Tıbb-1 Kanunî" adı altunda yer almış ve bu dersin ilk hocası da yine Doktor Bernard olmuştur. Ayrica Türkiye'de 1909 yılından itibaren Hukuk Fakültesi ders programlarunda adlî tup dersleri önceleri seçmeli, daha sonra da mecburî olmak üzere okutulmaktadır. ${ }^{101}$ Konunun uzmanlarının ortak görüşü; "tıbbî otopsilerin, ilmin gelişmesi için şahıslanı ölümüne sebep olan hastalıkları anlamak ve aynı zamanda tup öğrenimi gören talebelerin bilgi ve tecrübelerini artırmak için yapıldığı" yönündedir. ${ }^{102}$

Osmanlı idaresi de Tıbbiye'de okuyan talebelerin otopsi ameliyatlan için gerekli olan bilgi ve beceriyi eksiksiz olarak ögrenmelerine çaba göstermiş, bu doğrultuda derslerin uygulamalı bir şekilde sürdürülmesi için çeşitli kanallardan kadavra teminine çalışılmışur. Bugün dahi, kitaplarda teorisini okurken gerçekle yüz yüze geleceğini o güne kadar düşünememiş hekimlerin varlığından bahsediliyor olması ${ }^{103}$ bu girişimin yerindeliğine işaret etmektedir. Hekimbaşı'nın 1847 senesinde Sadaret'e takdim ettiği bir tezkereden anlaşıldığı üzere Mekteb-i Fünûn-1 Tibbiye-i Şahane teşrihhanesi için başlangıçta Sultan'ın iradesi doğrultusunda Tersane-i Amire Hapishanesi'nde ölenlerden istifade olunmuştur. Daha sonra bu usulden vazgeçilerek, uygulamalı otopsi derslerinde kullanılacak cesetlerin esir pazanndan temini yoluna gidilmiştir. Lakin esir pazarının da ilga edilmesi sebebiyle uzunca bir müddet uygulamalı otopsi derslerine ara verilmek zorunda kalınmıştır. Bundan dolayıdır ki Hekimbaşı söz konusu tezkeresinde otopsi derslerini uygulamalı olarak anlatmadıkça, yani sadece kitap okumakla arzu edilen faydanın sağlanılamayacağına dikkat çekiyordu. Ona göre; otopsi derslerindeki bu aksayışın ortadan kaldırılmasının yolu yine

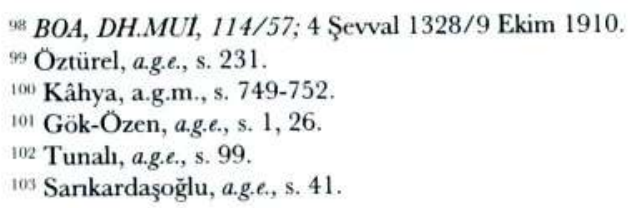


ölen cariye ve gulamların düzenli ve sürekli bir vaziyette Tıbbiye'ye gönderilmelerinden geçmektedir. Bu gönderim işinin de belirli bir düzen içerisinde sürdürülebilmesi için ölenlerin hemen mektep idaresine bildirilmeleri gerekmektedir. Bu noktada kendilerinden istifade olunacak zümre esircilerdir. Onlara meseleye dair açık ve sıkı bir uyarıda bulunulacak, bu işi teşvik için ölenleri haber verecek olan her bir esirciye 30 kuruş "ihbariye" ödenecektir. Sadaret, Hekimbaşının bu tekliflerinden özellikle cesetlerin mektep tarafina sevkini oldukça yerinde bulmuş, ihbariye ücretlerinin ödenip ödenmemesi konusunda kesin bir hükme varabilmek için Sultan Abdülmecid'e danışmak gerektiğine dikkat çekmiştir. ${ }^{104}$

Daha sonraki yllarda otopsi derslerine kadavra temininde istifade olunan bir diğer kaynak ise Darülaceze'de ölenler olmuştur. Mesela, 10 Nisan 1911 tarihli bir vesikada Darülacezede ölen Mişon Mandil isimli şahsa ait ceset üzerinde otopsi ameliyat icra olunmak için cesedin Tıp Fakültesi'ne gönderildiği kayıtlıdır. ${ }^{105}$ Ancak Darülaceze'den ceset temin etmek daima Mişon Mandil örneğindeki gibi her zaman sessiz sedasız gerçekleşmemiştir. Nitekim Hasköy'ün Hacı Şaban Mahallesi'nin Yahudi sakinelerinden olup, fukaralıktan Darülaceze'ye nakledilen ve 1914 senesinde orada ölen Yasef kızı Refika Hatun'un cesedinin Tıp Fakültesi'ne gönderildiğini haber alan akrabalan bir yaygara koparmış ve soluğu hemen Hahamhane'de almışlardır. Durumdan haberdar edilen Hahambaşı, derhal Adliye ve Mezahip Nezareti'ne başvuruda bulunarak; Yahudilerin öldükten hemen sonra kendi cemaatlerine mensup şahıslarca yıkanı, kefenlenerek defnedilmelerinin gerekliliğinin ${ }^{106}$ mezheplerinin bir hükmü olduğunun ve bundan sonra da Darülaceze'de ölecek olan Museviler hakkında bu hükme uyulması gerektiğinin ilgililere bildirilmesini istirham edecektir. Bunun üzerine Adliye ve Mezahip Nezareti yaptğı tahkikat neticesinde yakınları bulunan veyahut bir mahkeme kararıla üzerinde otopsi ameliyatının icrası lüzumu hâsl olmayan ölülerin Tip Fakültesi'ne gönderilmelerinin herhangi bir gerekçesinin olmadığı yönünde Dâhiliye Nezâreti'ne bir haturlatmada bulunmak suretiyle Yahudileri haklı bulduğunu ortaya koyacaktur. Dâhiliye Nezâreti bürokratları ise kendilerini haklı çıkarmak için şöyle bir savunma hazırlamışlardır: Bu uygu-

IH BOA, I.DH, 144/7419; 6 Cemaziyelevvel 1263/22 Nisan 1847.

${ }^{105}$ BOA, MF.MKT, $1170 / 46$; 27 Rebiyülâhir 1329/27 Nisan 1911.

106 Gerçekten de Tevrat'ta cesedin muhakkak surette gömülmesi gerektiğinin haricinde; bir cesedin parçalanmasının veya rezil edilmesinin yasak olduğundan bahseden hükümler vardır (Tensiye, 21:22-23). Ayrica bir cesetten herhangi bir çıar elde etmek de yasaktır (Avoda Zara, 29b). Bkz. Yusuf Besalel, Yahudilik Ansiklopedisi, II, (Basım Yeri Belirtilmemiş), 2001, s. 464. Ancak İncil'de ve Kuran'da insanlar üzerinde otopsi yapılamayacağına dair bir kayt olmamasına rağmen gerek Hristiyan gerek İslam âleminde ne ilmin ilerlemesine katkı sağlamak ne de adli olayların aydınlatulabilmesi adına uzunca bir süre otopsi ameliyat icra olunabilmiştir. Bkz. Tunalı, a.g.e., s. 99. 
lama bütün hastanelerde geçerlidir. Darülacezede kalırken bir hastalıktan ötürü ölenlerin ve ölmeden evvel hastalıklarına teşhis konulamayanların cinsiyet ve mezhep ayrımı söz konusu olmaksızın Tıp Fakültesi'ne sevk olunmalan genel bir kaidedir. Kaldı ki Refika Hatun, Darülaceze'nin Musevi müstahdemince ve mezheplerinin gereklerine uygun surette yıkanıp, kefenlendikten sonra fakülteye sevk olunmuştur. Ancak Osmanlı bürokratlarının savunma raporlanına sıkışturdıklan bir nokta daha vardır ki o da böyle bir uygulamanın esas maksadını ele verecek türdendir: "Darülaceze'de ölenlerin cesetleri üzerinde gerçekleştirilen otopsi ameliyatlan sayesinde Tıp Fakültesi'nde öğrenim gören talebelerin malumatları da artmaktadır."107 Yoksa çok olağanüstü haller dışında Darülaceze'deki ölümlerin yaşlılık ve ona bağhı faktörlerden mütevellit olduğu aşikârdır.

\section{Sonuç}

Osmanlı İmparatorluğu Tanzimat Fermanı'nın ilanı (1839) ile birlikte çağının değişmekte olan şartlarına uygun olarak idaresindeki bireyleri ve onların temel haklarını güvenceye almak istemiştir. Ülkedeki mevcut hukukî yapı da bunu tek başına sağlama noktasında kendisinden beklenileni karşlayamayınca hukuka yardımcı unsurlann gelişmesi ve devreye girmesi gerekmiştir. İşte böylesi bir süreçte Osmanlı İmparatorluğu'nda adlî tup giderek önem kazanırken, aynı zamanda kökleşmeye de başlamıştur. Kimileri için bu sancılı bir süreç olmakla beraber, Tanzimat'ın getirdiği doğal bir zorunluluktan başka bir şey de değildir. ${ }^{108}$ Osmanlı adlî tubbı ve onun çatısı altunda girişilen otopsi ameliyatlan nasıl bir süreçte ve ne şekilde ortaya çıkmış olursa olsun metin içerisindeki örnek hadiselerde de görüldüğü üzere hem merkezî idare açısından hem de Osmanlı insanlan için eşsiz bir hukukî güvence oluşturmuştur. Bu sayede ölümü meydana getiren unsurlara, kimliğe ve varsa sanıklar hakkında önemli detay bilgilere ulaşılabilmiş, dolayısıyla adaletin doğru bir şekilde ve zamanında yerine getirilmesi sağlanabilmiştir.

Osmanlı çağının otopsiyi ilgilendiren gelişmeleri bugünün modern ardıllan için de sağlam bir altyapı oluşturmuştur. Bu sayededir ki; teknolojik ilerlemeler dışında gerek otopsileri icra eden Osmanlı tabiplerinin bilgi ve becerileri, gerekse öncesi ve sonrasıyla otopsi ameliyatları çağdaşlanından ve bugünkülerden çok geri bir seviyede bulunuyor olmak gibi bir yargyya mahkûm edilmekten kurtulmuştur. Nitekim otopsinin amaçlanndan olan ölüm sebebinin ve biçiminin belirlenmesi noktasında Osmanlı tabipleri vazifelerini başarıyla yerine getirmişlerdir. 


\section{KAYNAKÇ.A}

\section{Başbakanlık Osmanl Arşivi (BOA) Belgeleri}

(Dosya No/Gömlek No; Hicrî-Rumî/Miladî tarih şeklinde gösterilmiştir.)

\section{A.Sadaret Evrakı}

Sadaret Mühimme Kalemi Evrakı (A.\}MKT. MHM)

563/13; 25 Şevval 1311/1 Mayıs 1894.

Sadaret Mektubî Kalemi Belgeleri (A.MKT)

35/87; 18 Safer 1262/15 Şubat 1846.

Bâb-1 Âlî Evrak Odası (Arşivi) Belgeleri (BEO)

1829/137151; 7 Muharrem 1320; 16 Nisan 1902.

1853/138904; 16 Safer 1320/25 Mayss 1902.

1853/138937; 16 Safer 1320/25 Mays 1902.

1935/145123; 14 Recep 1320/17 Ekim 1902.

2111/158285; 13 Rebiyülâhir 1321/9 Temmuz 1903.

2197/164719; 25 Recep 1321/17 Ekim 1903.

\section{B.Yıldız Evrakı}

Yıldız Esas Evraku Defterleri (Y.EE.d)

1090

Yıldız Perakende Evraku Zaptiye Nezareti Maruzatı Analitik Envanteri (Y..PRK.ZB..)

5/21; 25 Cemaziyelevvel 1307/17 Ocak 1890.

10/102; 12 Cemaziyelâhir 1310/1 Ocak 1893.

Yıldız Mütenevvî Maruzat Evraka (Y.Mtv)

95/43; 4 Zilhicce 1311/8 Haziran 1894.

Yıldız Perakende Evrakı Şehremaneti Maruzâtı (Y..PRK.ŞH..)

4/83; 22 Şevval 1311/28 Nisan 1894.

G.Nezaretler Evraka

Dâhiliye Nezareti (DH.)

Dâhiliye Nezareti Mektubî Kalemi (DH.MKT.)

501/53; 3 Safer 1320/12 Mayis 1902. 
569/37; 28 Cemaziyelevvel 1320/2 Eylül 1902.

606/25; 1 Şaban 1320/3 Kasım 1902.

700/15; 2 Safer 1320/11 Mays 1902.

1045/24; 3 Zilhicce 1323/29 Ocak 1906.

1342/5; 7 Muharrem 1301/8 Kasim 1883.

2110/105; 10 Cemaziyelevvel 1316/26 Eylül 1898.

2461/86; 23 Zilkade 1318/14 Mart 1901.

2519/7; 20 Rebiyülâhir 1319/ 6 Ağustos 1901.

\section{Dahiliye Nezareti Muhaberât-ı Umumiye İdaresi Belgeleri (DH.MUi.)}

9-1/23; 27 Şaban 1327/13 Eylül 1909.

21-2; 26 Ramazan 1327/11 Ekim 1909.

43-1/11; 12 Zilhicce 1327/25 Aralık 1909.

58/50; 17 Muharrem 1328/29 Ocak 1910.

108-1/17; 19 Cemaziyelâhir 1328/28 Haziran 1910.

114/57; 4 Şevval 1328/9 Ekim 1910.

Dahiliye Nezareti Hukuk Kismu Belgeleri (DH.H).

15/10; 5 Mart 1329/18 Mart 1913.

Dahiliye Nezareti Emniyet-i Umumiye Müdüriyeti 6. Şube (DH.EUM.6.Şb)

51/29; 24 Ramazan 1333/5 Ağustos 1915.

Dahiliye Nezareti Emniyet-i Umumiye Müdüriyeti 3. Şube (DH.EUM.3.Şb)

10/57; 13 Safer 1334/21 Aralkk 1915.

\section{Asayiş Kalemi Belgeleri (DH.EUM.AYŞ.)}

5/94; 20 Recep 1337/21 Nisan 1919.

5/101; 21 Receb 1337/22 Nisan 1919.

İdarî Kısım Belgeleri (DH.íD..)

116/86; 6 Cemaziyelâhir 1332/2 Mays 1914.

Dahiliye Nezareti Hukuk Müşavirliği Belgeleri (DH.HMŞ.)

2/3-01; 11 Recep 1334/14 Mayss 1916. 
Dahiliye İradeleri (İ.DH)

144/7419; 6 Cemaziyelevvel 1263/22 Nisan 1847.

Zaptiye Nezareti (ZB.)

301/41; 21 Haziran 1319/4 Temmuz 1903.

302/33; 3 Ramazan 1321/23 Kasım 1903.

302/39; 30 Temmuz 1321/12 Ağustos 1905.

303/159; 7 Kanunusani 1321/20 Ocak 1906.

345/50; 27 Nisan 1322/10 Mayss 1906.

345/108; 27 Haziran 1322/10 Temmuz 1906.

468/55; 11 Mayıs 1322/24 Mayıs 1906.

479/28; 23 Eylül 1323/6 Ekim 1907.

40/99; 1 Teşrinisani 1323/14 Kasım 1907.

492/3; 2 Kanunuevvel 1324/15 Aralık 1908.

349/94;13 Haziran 1325/26 Haziran 1909.

Hariciye Nezareti Mektubî Kalemi (HR.MKT)

61/88; 29 Şevval 1269/5 Ağustos 1853.

Maarif Nezareti Mektubî Kalemi (MF.MKT)

1170/46; 27 Rebiyülâhir 1329/27 Nisan 1911.

D.Teftişat-ı Rumeli Evrakı (Rumeli Müfettişliği)

Manastur Evraka (TFR.I..MN..)

15/1421; 25 Cemaziyelevvel 1321/19 Ağustos 1903.

72/7161; 26 Cemaziyelâhir 1323/28 Ağustos 1905.

Selânik Evraka (TFR.I..SL..)

7/649; 29 Zilhicce 1320/29 Mart 1903.

Rumeli Müfettişliği Arzuhalleri (TFR.I..ŞKT.)

5/478; 17 Zilhicce 1320/17 Mart 1903.

E.Şûra-yı Devlet Belgeleri (ŞD)

2731/26; 6 Recep 1321/28 Eylül 1903. 


\section{Araşturma-İncelemeler}

Adli Tıp Kurumu Kanunu Döner Sermaye Yönetmeliği Ve Fiyat Listesi, (Adli Tıp Kurumu Yayınları), İstanbul 1983.

Aykan, Talia Balı, Otopsi Tekniği ve Yardıma Bilgiler (I.Kitap), İstanbul 1986.

Balcı, Yasemin, Herkes İ̧in Adli Tip Cep Kitabı, Eskişehir 2008.

Besalel, Yusuf, Yahudilik Ansiklopedisi, II, (Basım Yeri Belirtilmemiş), 2001.

Bingöl, Sedat, "Tanzimat İlkeleri Işı̆̆ında Osmanlı'da Adli Tababete Dair Notlar", Tarih Araştırmalan Dergisi, C.XXVI, S.42, Ankara 2007, 37-65.

Gök, Şemsi, Adli Tip Dün, Bugün ve Yann, İstanbul 1995.

Gök, Şemsi, Adli Tip, İstanbul 1991.

Gök, Şemsi Özen, Cahit, Adli Tıbbın Tarihçesi ve Teşkilatlanması, İstanbul 1982.

Günergun, Feza-Yıldırım, Nuran, "Cemiyet-i Tıbbiye-i Şahane'nin Mekteb-i Tıbbiye-i Şahane'ye Getirdiği Eleştiriler (1857-1867)", Osmantı Bilimi Araştırmalar, C.III, S.1, İstanbul 2001, 19-63.

Hancı, İ.Hamit, Adli Tip ve Adli Bilimler, Ankara 2002.

Kahya, Esin, "Bizde Disseksiyon Ne zaman ve Nasıl Başladı", Belleten, C.XLIII, S.172, Ankara 1979.

Örsal, Metin-Katkıcı, Ufuk, Adli Rapor, Sivas 1991.

Özden, Salih Yaşar, Adli Tip El Kitabr, İstanbul 1993.

Özen, H. Cahit, Adli Tip Ders Kitabr, İstanbul 1980.

Öztürel, Adnan, Adli Tip, Ankara 1971.

Polat, Oğuz, Adli Tip, İstanbul 2000.

Polat, Oğuz-İnanıcı, Mehmet Akif-Aksoy, Mustafa Ercüment, Adli Tip Ders Kitabl, İstanbul 1997.

Sarıkardaşoğlu, İhsan, Adli Tipta Ana Konular ve Ömeklerle Rapor Yazma Tekniği, Eskişehir 1990.

Simpson, Cedric Keith, Adli Tip, (Ed. Bernard Knight), İstanbul 1995.

Soysal, Zeki - Eke, S.Murat-ÇAĞDIR, A.Sadi, Adli Otopsi, I, İstanbul 1999.

Tunalı, İbrahim, Adli Tip, Ankara 2001.

Unat, E. Kadri Samastı, Mustafa, "Mekteb-i Tıbbiye-i Mülkiye", I.Türk Tıp Tarihi Kongresi, Ankara 1992. 


\section{Başvuru Eserleri}

Devellioğlu, Ferit, Osmanluca-Türkģe Ansiklopedik Lugat, Ankara 1993.

Dökmeci, İsmet, Türkģe Tip Terimleri Sözliuğü, İstanbul 2006.

Kocatürk, Utkan, Açılamah Tıp Terimleri Sözlüğü, Ankara 1997.

Pakalın, Mehmet Zeki, Osmanl Tarih Deyimleri ve Terimleri Sözlüğü, I, II, III, İstanbul 1983.

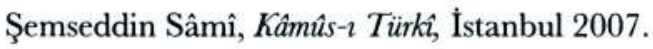

Tuğlacı, Pars, Tip Sözlïğü, İstanbul 1973.

Unat, Ekrem Kadri-İhsanoğlu, Ekmeleddin-Vural, Suat, Osmanlca Tip Terimleri Sözlüğï, Ankara 2004. 